\title{
$J(\Theta)$
}

Received: 05.05.2020

Accepted: 17.05 .2020

Published: 14.06 .2020

JOTS, 4/2 2020: 376-436

\section{Runik Harfli Eski Türk Yazıtlarındaki Ses Olayları}

\section{Phonetic Cases in Old Turkic Inscriptions with Runic Script}

\author{
Mehmet HAZAR \\ Düzce University (Düzce/Turkey) \\ E-mail: mehmethazar@duzce.edu.tr
}

In this study, the phonetic cases in Old Turkic Inscriptions marked with Köktürk, which are based on Orkhon Turkish, are emphasized. First, an introduction was made with a short language history based on the literature research. Then, with the emphasis on the phonetic cases, a transition to scrutiny was made. In phonetic cases, first the vowels and then consonants were emphasized. According to the examples, examples of sound events were given with sub-items. This limited phonetic analysis was not compared to later Turkish dialects. It was made according to the borrowed languages and use of words in the text. Findings of new studies on voice changes were also attempted to be transferred here. Sample words are grouped under the title of 46 items. An example of the uncommon was given, a few of the common ones were given. The situations at the beginning, inside and after the words and suffix sound changes were shown. Five main items were identified in the in the conclusion. Then, suggestions and evaluations were made. Signs and bibliography have been added to the back.

Key Words: Old Turkic, Orkhon Inscriptions, phonetic cases, sound changes. 


\section{$J(\Theta)$}

\section{Giriş}

Bütün proto dillerin takribi başlangıç noktası diğer bir ifadeyle bir üst zaman limiti vardır ve bu zaman aralığı çoğunlukla Mezolitik (Orta Taş Çağı-MÖ 22.000-10.000) dönemin sonu veya Neolitik (Cilalı Taş Devri-MÖ 1900) dönemin başı olarak tahmin edilir. Bu Cilalı Taş Devri kabaca 2,5 milyon yıllık insanlık tarihinde çok önemli bir dönüm noktasına işaret eder. Bu ziraata dayalı neolitik toplumların, siyasi erki de kapsayan biçimiyle gelişmiş örnekleri Mezopotamya'da 5.500 yıl öncesinden beri ortaya çıkan ve yazılı tabletlerinde Türkçe kelimelerin bulunduğu Sümer şehirleridir. Bu kentlerin oluşumu aynı zamanda tarih öncesi neolitik dönemin bitişini ifade eder. 12000 yıl önce Neolitik Devrim denen tarım devrinde meydana gelen dilin içtimai şartları, bugün bilinen anlamda dillerin tezahürü neticesini doğurmuştur. Proto Türk dili bu devirde kullanılmış bir dil ise başlangıç noktası MÖ 4500-4000 yıllarıdır. Eğer Proto Türk dilinden daha arkaik bir dil, mesela Proto Altay dili varsa, Proto Türk dili bu lisan çözüldüğü dönemde tezahür etmiş olmalıdır. Proto Türk dilinin alt zaman limiti ise mevcut Türk dil ve lehçeleriyle ilgili ilk verilere tesadüf edilen devir yani MS ilk bin yılın ortaları olmalıdır (Brendemoen 1998: 68).

Altay dil teorisini daha da genişleten Avrasyatik dil teorisi bağlamında Türkçe (Arıkoğlu 2007: 112) ve Farsça (Rezaei 2013: 30) denklikleri de dikkate al1nınca Türk dilinin karanlık devri ${ }^{1}$ (Mermer 2009: 5) kuramsal olarak İlk Türkçe ${ }^{2}$ (Çuvaş dil birliğinin başlangıcı Sümerce denkliklerden dolayı MÖ 3500 yıllar, bitişi ise MÖ 500'lü yıllara kadar) ${ }^{3}$ Hahameniş Dönemi Eski Persçesinin (MÖ 559-

\footnotetext{
1 Rus bilginleri Tolstov ve TROFImova'ya göre MÖ binli yıllara delalet eden, Sümerlileri andıran ve dilleri Türkçeye benzeyen ırklar Turan ovasında yaşamaktaydı. Bunların Avesta'da geçen 'Tûr'a' boyu oldukları sanılmaktadır (Esin 1978: 25). İlk Türkçe kelimelerin tespit edildiği Sümerce metinler MÖ 3100, yok olduğu düşünülen metinler ise MÖ 1800 tarihine denk gelmektedir. Türkler MÖ 3500 y1llarında bugünkü Türkiye'nin doğu bölgesinde idi (Tuna 1990: 259-289).Türk dilinin tarihî (karanlık) dönemleri için yaygın olarak kullanılan adlar şunlardır: 1. Altay Devri 2. En Eski/ilk/Ana/Erken Ana Türkçe Devri ‘Pre Turkic/Proto Turkic', 3. illk / Ön / Ana / Geç Ana Türkçe Devri ‘Pre Turkic / Proto Turkic' (Karademir 2016: 550).

2 İlk Türkçe devresi, İlk Türkçe I ve İlk Türkçe II olarak iki dönemde tetkik edilmiştir (Ceylan 1997: 39).

3 'Erken Ana Türkçe MÖ 3000- MÖ 500' (Róna-Tas 2013: 49). Geç Ana Türkçe Devri/Ön Türkçe Devri, Ana Türkçe Devri: Çağdaş Türk lehçelerinin oluştuğu dönemdir. Tahminen MÖ X-IV. asırdır (Akar 2006:
} 


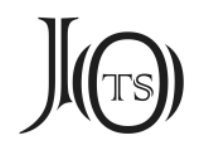

330) ve Çinlilerin Hiong-nu dediği Hunların (MÖ III. yüzyıl, MÖ 46 Doğu Hun ve Batu Hun, 246'ya kadar) dili Ana Türkçe ${ }^{4}$ (milat sıralarından başlayıp VII. yüzyıla kadar) Eski Farsça (MÖ 550-330) yani I. Fetret Dönemi (MÖ 331-MS 224) Sâsânî ‘İkinci' Pers İmparatorluğu (224-651) devri Partça, Soğdca, ${ }^{5}$ Harezmce ${ }^{6}$ ve Hotancasının, Aşina ${ }^{7}$ boyunun kontrolünde (Ôsawa 2011: 253) ebedileşmiş yazı dili olan Eski Türkçe (Orhon, Uygur ve Karahanlı Türkçesi) ise Orta Farsçanın (Sakaca ve Baktrcenin, MÖ 330-MS 651) tarihine yakın bir döneme (VII-IX. asra) denk gelir (Rezaei 2013: 30 ve Eker 2010: 322). ${ }^{8}$ Berçik ‘Fars, kavim adı' (KT K12) sözcüğü bu Farsça ve Türkçe münasebetine olan tanıklığın bir hatırası olmalıdır.

Avrupa-Asya ve Asya Runik alfabesi olarak ilk önce iki temel gruba ayrilıp XIII. yüzyılda tamamen terk edilen (Barutçu 2002: 203) Köktürk işaretleriyle yazlya geçirilen Eski Türkçenin ilk lehçesi olan Orhon Türkçesi 682 tarihli Çoyren yazıtıyla gün ışığına çıkar. W. RADLOFF ve V. THOMSEN ile başlayıp A. BOMBACi'ye ${ }^{9}$ ve

54). Bu dönemi Ana Türkçe diye olarak adlandıranlar, dönemin I-V. asırları ihtiva ettiğini düşünmektedirler (Korkmaz 2003: LXXIV; Üstüner 2015: 44). Ana Türkçe (Milât-MS V. yüzyıl) (Eker 2006: 111). Ana Türkçe (I.-VI. asırlar) (Tekin-Ölmez 2003: 16). Ön Türkçe Devri: MÖ XVII. asırdan II. asra kadar sürdüğü tahmin edilen bu devrin sonuna doğru, Türkçe (r-l z-ş) değişmesi neticesinde tarihi lehçelere ayrılmıştır (Güneş 2002: 22). Geç Ana Türkçe MÖ 500- MS 400 olarak tahmin edilmektedir (RónaTas 2013: 49).

4 Türklerin atası Hunların diline ait tören kılıcı anlamına gelen ve Çin kaynaklarında geçen king-lo'nun yazıya geçmiş en eski Türkçe kelime olduğu düşünülmektedir. IV. yüzyıl başlarından kalan ve Çince kaynakta anlamı da verilen Süke tıllkang/Bukuk-gu tutang '(Düşman) ordusuna karşs çıkın, Bukuk'u (lideri) tutsak alın!' şeklindeki dize de ilk Türkçe metinlerdendir (Mermer 2009: 5).

5 'Birinci Türk Kağanlığı dönemine ait ilk yazılı belge sayılan ve tipik Göktürk mezar kitabeleri özelliklerini taşıyan Bugut Yazıtı"nın toplam 29 satırdan oluşan üç yüzü Soğdca idi’ (Eker 2010: 325).

6 Horezm Harezm Türkçesi değil, Farsçanın tarihi bir lehçesidir.

7 Hunlarınn (匈奴 xiongnu) farklı bir soyu (別種 biezhong) olup farklı/bağımsız bir bölük (部落 buluo) hâline gelen Türklerin (突厥 tujue ‘Göktürkler') soyadları (姓 xing) 阿史那 Ashina’dır (Erkoç 2018: 54).

8716 yılında Hazar kıyılarına yakın Sul adlı Türk beyinin yönettiği Gurgan bölgesini Emevi Yezid bin Muhallab ele geçirdi. Emevî komutan Mesleme damadı Saîd b. Abdülaziz'i 720 yılında Horasan'a vali tayin eder ve Saîd ile Türk hakanı Kürsûl savaşır. Mesleme MS 731 yılında Türkler'in üzerine yürümüş, fakat Kafkas kapılarına ulaştıktan sonra daha da iç kesimlere ilerlemekten çekinerek geri dönmüştür (Haciyev 2010: 137).

9 Köktürkçeye ait 'şad' unvanı ile ilgilidir (Bombaci 1974: 167). 


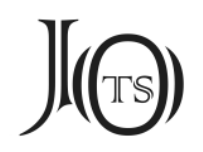

C. ALYIMAZ ${ }^{10}{ }^{10}$ kadar süren irdelemelerin konusu olan ve runik olarak adlandırılan Eski Türk yazıtlarında unvanlar dâhil olmak üzere yaklaşık 1000 ayrı sözcük mevcuttur (Ölmez 1995: 227).

Moğol tarihçisi Alaaddin Atâ' Melik Cüveynî (1226-1283) 1252-1260 yılları arasında üç cilt olarak kaleme aldığı Tarih-i Cihan-Güşa'sında ('İdikut'un Soyu ve Uygur Şehirleri' bölümünde Ordu Balık'ta (Karabalsagun = Mo. Harbalgas'ta) runiform alfabe ile yazılmış eski Türk yazıtlarından ilk söz eden kişidir. Bu bahsedilen üç dilli I. Karabalgasun yazıtı olabilir. Nicolae MiLEscu (1636-1703) Rus Çarı Aleksi MiHAYLoviç’in elçisi olarak Çin imparatorunun sarayına giderken (1675) Yenisey Irmağı civarında gördüğü bazı kaya yazıtlarını tasvir eder. Semen Ulyanoviç REMEZov 1697 yılında yazdığı ve oğulları tarafından 1701 yılında tamamlanan Çertejnaya Kniga Sibiri'de bazı Yenisey yazıtlarının resimleri ve yazıtların metni hakkında malumat vermektedir (Aydın 2015: 27; Sever 2019: 286). Altay dilleri üzerine son teferruatlı malumatta Ana Türkçe, Türküt, Doğu Türküt, Eski Türkçe ve Köktürk işaretli Orhon Yazıtları silsilesiyle bütün Türk Dili ve üyeleri şematik olarak gösterilmiştir. (Blažek 2019: 86).

Resimden (pigdogramdan) düşünce yazısına (ideograma) geçiş ${ }^{11}$ olan Köktürk işaretli (runik) yazıtlar keşfedildikleri 1721 yılından 2017 yılına (Aydın 2019: 7) ve runologistlerce deşifre edildikleri 1893 yllından yeni keşif ve deşifrelerle (Alimov ve Tabaldiev 2005: 125) günümüze kadar gerek Türkiye'deki gerekse yurtdışındaki Türklük bilimi âleminde çok ilgi görmüştür. (Scharlipp 2004: 309) Bugün Azerbaycan'da takdire şayan bir ilgi ${ }^{12}$ olsa da alan yazınında ses yapısı ve ses özelliklerinin korunması dışında 'ses olayları' ile ilgili satır araları hariç bağımsız bir irdelemenin olmadığı anlaşılmaktadır (Aydın-Güner 2007: 33). Ses olayları ise ses birliklerinin artikulatorik (mahreç; dudak, diş, damak ve gırtlak

10 Engin Türkistan coğrafyasında uzun yıllar yapılan tetkikler neticesinde kadim Türk kültür ve medeniyeti, eski Türklerin hayatı ve inanışı, eski Türk dilinin ilk yazılı abideleri olan (Kök)türk harfli yazıtlar ile ilgili ciddi bir arşive ve bilgi birikimine sahip olunmuş ve bunlar yurt içinde ve yurt dışında konuyla ilgili olan kongre, sempozyum ve konferanslarla paylaşılmıştır (Alyılmaz 2018: 4).

111889 yllı Helsinki'de neşredilen XXXII. Kara-Jous yazıtındaki bu geçiş rahatlıkla müşahede edilmektedir (Scharlipp 2004: 318)

12 Azerbaycan Merkez Bankası tarafından beş manatının arka yüzünde Köktürk işaretleri 2005 ve 2009 baskısında resmedilmiştir: Türük bodunug adı küsi yok bolmazun tiyin kąım ... kagan olurtum (KT D25). 


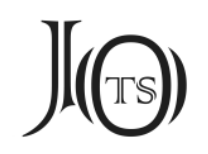

olarak seslerin çıkartılması) ve akustik (yankıbilim) özellikleri göz önüne alınarak yapılmaktadır (Coşkun 2011: 347).

Ölçünlü yani yazılı dili olarak en az 1300 yıllık bir tarihe sahip olan Türk dili, ${ }^{13}$ süreç içerisinde hem kendi dil yapısından kaynaklanan gelişmelerle hem de kültürel ilişkiye girdiği diğer dillerin etkisi ile değişimlere uğraması Eski Türkçe döneminde yazılı olarak görülmeye başlamıştır. Genel olarak ses olayları; ses türemesi, ses düşmesi ve ses değişimi biçiminde ortaya çıkar (Sevinçli-Çiçek 2019: 1235, 1264). Dil birliklerini sözcük olarak oluşturan sesler tesadüfî bir şekilde bir araya gelmezler. Sesler boğumlanma yerleri ve biçimleri bakımından birbirinden farklılaşır. Bazı durumlarda benzer sesler yan yana gelirken kimi hâllerde de seslerin tekrara düşüp telaffuz zorluğu çıkardığı için aykırılaştı̆̆g da olur. Türkçede sıkça rastlanılan ses olaylarının bir kısmı (ses düşmesi, ses benzeşmesi, kaynaşma vb.) konuşma sırasında çabadan ve zamandan tasarruf ederek konuşmada kolaylık sağlamak gayesiyle yapılır. Bir dilbilgisi terimi olarak buna en az çaba kuralı denir. Dilde, oldukça mantıklı gelen bu durumun tersine kelimenin söyleyişinde daha çok çaba isteyen değişimler de yani 'en çok çaba yasası’ olabilmektedir (Öztürk 2017: 2182). Bu değişimlere ünlü türemesi, ünlü genişlemesi, ünlü kalınlaşması, ünsüz türemesi, ünsüz ikizleşmesi gibi fonetik hadiseler misal olabilir. Ayrıca, kaynak dilden (tarihî dönemdeki lehçeden veya yabancı dilden) gelen ve Türkçenin şekil hususiyetlerine tabi olmayan birtakım kelimelere Türkçe ifade hususiyeti kazandırıldığı hâllerde de ses olayları görülmektedir. Ses olayı, çoğu vakit dil seslerinin oluşturdukları anlamlı ve görevli ses birliklerinde uğradıkları değişiklikler iken bazen anlam değişikliği oluşturmayabilir.

13 Moğolistan'daki ‘Sansat-Ula/Baga Sansar' dağının güney eteğindeki kurganda bulunan Çoyr(en) Yazıt1 682-691 'II. Göktürk Kağan Dönemi mezar taşı olarak dikilen anıt' (Klaştornıy 1969: 9): (e)lt(ä)r(i)ş

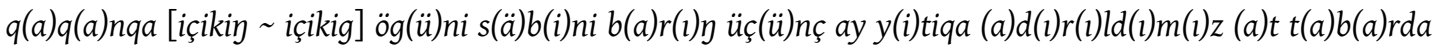
tun b(i)lgä [şad Çad] tun [y(ä)g(ä)n yeg(ä)n] (ä)rkin [tulku] b(i)t(i)d(i)m ırk [açıg] (a)yg(i)l bana ‘ilteriş Kağan'a tâbi olun. Öğünüp sevinerek yaşayınız. Üçüncü ayın yedisinde ayrıldık attan davardan Tun Bige Şad Tun Yeğen Erkin. Yekpare yazdım. Falı (kaderi) acı de bana'. Bk. içik- 'tabi olmak' (KT D10, Moyun Çor D6-7), tulku 'yekpare' (Tar. B3), çad 'yüksek bir unvan', y(ä)g(ä)n yeg(ä)n ‘yeğen' (Suci 8), açıg 'acı' (Ozn. I) (Tekin 2003: 237-259). Irk Bitig’te fal ve kader anlayışı için bk. "Şimdi sevgili çocuğum, şöylece biliniz: Bu fal kitabı iyidir. Fakat (yine de) herkes kendi kaderi üzerinde güç sahibidir." (Tekin 2004: 34). 


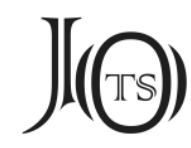

Ses olayları ünlü uyumu, bağlanma ünlüsü, ünsüz uyumu; ünsüz-ünlü benzeşmesi, ünsüz korunması, ünsüz benzeşmesi, ünlü değişmesi, ünsüz değişimi (yumuşaması), ses düşmesi, ses türemesi ${ }^{14}$ ünlü daralması, aykırılaşma, göçüşme (yer değiştirme) vb. ses etkileşimlerinden oluşan ses olaylarıdır (Coşkun 2011: 365). Ses olayları eş zamanl, art zamanlı ve betimlemeli olarak üçe ayrılır.

Eski Türkçede ses olayları çoğunlukla karşılaştırma olarak dil gelişimi süreciyle örtüşecek şekilde [*Ana Türkçe > Eski Türkçe (Köktürkçe) > Orta Türkçe (Oğuzca) > Yeni Türkçe (Osmanlı Türkçesi) > Çağdaş Türkçe (Türkiye Türkçesi)] karşılaştırmalı olarak yapılırken nadiren eş zamanlı (Eski Türk Lehçeleri Köktürkçe, Eski Uygur Türkçesi ve geçiş lehçesi Hakaniye veya Karahanlı Türkçesi) olarak kendi içinde yapılır. Köktürkçeye göre Eski Uygurcadaki ve bazen DLT yani Karahanlıcadaki Eski Türkçenin üç lehçesini de içeren ses değişmelerinin incelemesi yapılmıştır (Erdal 2004: 86). Burada temel tarihî lehçe yani incelenen metinler Eski Uygur Türkçesine aittir. Eski Türkçe için betimlemeli (tasvirî, açıklayıc1) çalışma Rusça olarak yapılmıştır (Kononov 1980: 256). Bunun dışında sözcükler ve ekler incelenirken satır aralarında dip not olabilecek irdeleme ve açıklamalar yapılmıştır. Bu çalışmada eskicil ögelere de yer verildiğinden korunmalar söz konusu olduğu için tasarlanan İlk Türkçe (Pre-Turkic, ŞAZ 'Eski Doğu Türkçesi' ve LIRR 'Eski Batı Türkçesi', Çuvaş-Türk Dil birliği devri) ve öncelikle eskicil ve birincil uzunluklara ulaşmayı sağlayan Türk lehçelerinden (Çuvaşça gibi uzak lehçe olan 's grubu' ve uzunlukları diftonglar şeklinde koruyan Yakutça, eskicil olarak Köktürkçenin devamı olan ve aşırı şekilde uzun ünlüyü koruyan Halaçça ile uzun ünlülere yükselen diftong şeklinde sahip olan Yakutça ve uzun

14 Orhon yazıtlarından beri görülen ses türemeleri Türk dili tarihi dikkate alınınca daha azdır. Önce /y/ ve /h/ ünsüzü ile dar ünlüler türer. Birincil uzun ünlü kısalmasını sebep olduğu Ana Türkçeden gelen kelimelerde, sonra Türkçenin ses sistemine uydurulmasıyla alınma kelimelerde görülür. Uzun ünlünün kısalması ve dil dudak senkronizminin bozulması ses türemesinin temel sebebidir. Eklerde daha çok pekiştirme işlevindeki /n/ ünsünün görülmesinin sebebi ekin genişlemesinden kaynaklanır (Seninçli-Çiçek 2019: 1263). 
ünlü bulunduran Türkmen Türkçesinden) ${ }^{15}$ yeniden kurulan Ana Türkçe ${ }^{16}$ ile karşllaştırma da söz konusudur (Golden 2018: 9). ${ }^{17}$ Çünkü uzun ünlüler nitelik değişmesine uğrayıp ötümsüzleşme, ön seste türemesi, ünsüz ikizleşmesi, öndamaksıllaşma, ünsüz türemesi gibi 'seslik (fonolojik) izler' bırakmıştır (Hayırsever 2018: 277). 1963 yılından beri gelen bir birikimin neticesi olan 'Orhon Türkçesinin Grameri', ses bilgisi başlığı altında ünlü ve ünsüzler bölümlerine ayrılarak örnekleriyle çerçeveyi oluşturmuştur (Tekin 2003: 43-64).

$\mathrm{Bu}$ çalışma ise eski birikimlere yapilan 'yeni katkılar' da eklenerek Köktürk işaretli metinler (tasviri/betimlemeli gramer) ve gerekirse (art zamanlı/diyakronik gramer) 'daha eski tasavvurlar' üzerine yapıldı. Yukarıdaki kısa alan yazını irdelemesinden sonra aşağıda Orhon yazıtları ve ilgi çalışmalarda saptanan ses olayları sıralandı.

Bir sözcükte birden fazla ses değişmesi olunca aynı örnek birden fazla ses olayında gösterilmektedir.

15 Uzak Türk lehçelerini tarihi tam olarak bilinmeyen eski dönemlerde genel Türkçeden ayrıldığı için Çuvaşça, Yakutça ve Halaç̧̧a diye Türk dilinin kolları olarak isimlendirme uygun olabilir ancak yakın dönemde yazı dili olan ve anlaşma düzeyi yüksek olan ve en azından aynı dil grubu içerisinde yer alan bizim için Oğuz grubu içerisindeki Türkmen diyalektine Türkmen Türkçesi denmesi daha doğru olur. Kazaklar, Türkiye Türkçesine sadece Türik+şe (< türük <*török [> And. Ağz. türç k\# ve e\# ünsüzünün kelime kökü ve ekte ses düşmesiyle, Tür $\left.{ }^{k} c^{e}\right]$ ) demektedirler. Çok sayıda ortak sözcük sistemli olarak değişen ünsüz sistemine dayandığı $(/$ ș/ $/$ s/ sonra /ç/ > /ş/, /-y/ > /-j/, /t / > /d/, /b/ > /m/, /b/ > $/ \mathrm{v} /, / \breve{\mathrm{g}}-/>/ \mathrm{w}-/, / \mathrm{f} />/ \mathrm{p} /, /$ / $>/ \breve{\mathrm{g}} /, /$-va $/>/ \mathrm{o} /$ ve eklerdeki ünsüzlerde ileri seviyede ötümsüzlük ve akıcılı (sonant) uyumu) için öğrenilmesi kolaydır (Tamir 2003: 322).

16 İlk Türkçe [ ş < l > r > z; oguş 'boy' ve ogul 'evlat' gibi] Ogur ve Oguz < okur², ok 'boy, teşkilat']. /*ş/'nin zayıflayıp /l/'leşmesi de düşünülmektedir (Barutçu 2002: 204).

17 6. ve 7. dip nota bk. 


\section{$J(\Theta)$}

\section{I. Ünlülerde Ses Olayları}

\section{I.1. Birincil (Asli) Uzun Ünlünün Korunmas1 ${ }^{18}$}

Söz sonunda, söz içinde ve eklerde de uzun ünlü tespit edilmiştir (Tuna 1988: 227). Aşağıda sırasıyla görülecektir.

\section{1.}

Ana Türkçede olan birincil uzun ünlünün söz başında yazım özelliğinden dolay $1^{19}$ korunmuş olması fonemik anlam ayırt edici özelliktedir: āç 'aç, tok olmayan, acıkmak', āt 'ad' (Foy 1900: 192 193); āz 'az, birkaç, çok değil' (KTG 10) < İT (ilk Türkçe) b*hāŕ, āç- 'aç' (BK D38).

\section{2 .}

Ana Türkçede olan birincil uzun ünlünün kök sesleminde yazım özelliğinden dolayı korunmuş olması: uk/ku hece işareti: bu $u^{u} k a$ 'boğa' (Ata 2011: 150), $k^{u} u t$ 'talih', $k^{\circ}$ op 'çok', $k^{u} u b r a t-$ 'derletip toparlamak' (Tekin 2003: 34). özüm: kuutum : bar: üçün: kagan: olurtum : kagan: olurup : yok: çıgań : bodunug : koop : kuubratdım : 'benim (de) talihim olduğu için, hakan (olarak tahta) oturdum. Tahta oturup yoksul (ve) fakir halkı hep derleyip topladım.' (KT D29).

18 Kök vokalindeki birincil uzun ünlü kaybolurken bıraktı̆̆g ‘seslik iz, (sözcüğün diğer seslemlerinde de) ağırlık uyumunu' dengeleyerek ünlü genişlemesine, ünsüz türemesine, seslem türemesine, diftonglaşma (alçalan diftong) veya iç seslemde ünsüz türemesi, ünsüz ikizleşmesine (gemination) [ - *i:ki > Kzk. (y)eki/eki/äki - Yak. ve Çuv. ikki, *bịr > Çuv. piri 'bir, say1', Çuvaşçada *ūç > viz'z'e, üç >> viç 'üç'; *bi:ş > Karag. beyş 'beş, sayl', *āne >> (yazıda) anne 'ana'] ve üsüz ötümlüleşmelerine dengeleme prensibine bağlı olarak ses olaylarına neden olur. 'Normal vokalin teşekkülündeki ses telleri ihtizaz adedi uzun vokallerinkinden daha azdır. Uzun vokal normalleşince 'ağırlık uyumu' bozulur. Kaybı karşılamak ve dengeyi yeniden sağlamak için sonraki ötümsüz konsonun ötümlüleşmesi hal şekillerinden biridir. Böylece azalan vibration, eklenme suretiyle yeniden çoğalır; enerji uygun bölümlere dağıtılmış olur.' (Tuna 1988: 276-277).

19 Sözcük başında /a/ ve /e/ ünlüsünü gösteren işaret yazılmaz, yazılırsa birincil uzun ünlü kabul edilir. Uzun /ā/ ünlüsü a aç 'aç' (BK D38), āç- 'açmak' (BK K6), ât 'ad, unvan' (BK D41) sözcüklerinde yazılmıştır (Tekin 2003: 25). 


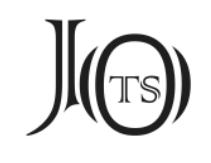

1.3. Birincil uzun ünlüden gelen ve sözcüğün kök sesleminde bulunan kapalı /é/ ${ }^{20}<* / i$ :/ ünlüsünün korunması: Yenisey yazıtlarında /é/ harfi ile yazılan sözcükler şunlardır: éki '2', él 'halk', éş 'arkadaş', ét- 'düzenlemek', bél 'bel', béş ‘beş', yéti 'yedi', yétmiş 'yetmiş’, kéş ‘sadak, okluk' (Ata 2011: 85).

\section{4 .}

Diğer uzun ünlüler: i 'orman', ì+gaç 'ağaç' T 25-26, yōk yook 'yok' (KTD 11), buuka 'boğa', (yazımda belli olmasa da) ur- [ūr-] 'vurmak', ${ }^{21}$ /uzun e/ èsni 'hatırla!' (Tuva I 3) (Tekin 2003: 46). Karşılaştırma ile anlaşılan başka uzun ünlüler de vardır (Tekin 2003: 49). Ancak yazımla anlaşılmadığından ve çalışmayı genişletmemek için bu örnekler üzerinde durulmadı. Bir örnekle yetinildi.

\section{5 .}

Birincil uzun ünlünün neden olduğu ses olayları şunlardır:

\subsection{1. Ünsüz Ötümsüzleşmesi}

Kök. (Orh.) öd 'öd, safra kesesi’ < AT *ō̄t , (Özek 2013: 652). Türkçede tek heceli sözcüklerden başka çok heceli sözcüklerin sonundaki /ç/, /k/, /k/, /t/ ünsüzlerin ötümlüleşmelerinin sebebi uzun ünlüyle alakalı olmasıdır (Tuna 1988: 275).

\subsection{2. Ünsüz Türemesi}

Aşağıda ünsüzler başlığı altında yeri gelince tekrar işlendi.

20 Ana Mo. için /e/, /é/, /ē/ ve /ế/ olmak üzere toplam dört e sesinin kabul edilmiş olunduğuna ve bunun birincil olup olmadığından kuşkulanıldığı belirtildikten sonra birincil /é/ sesinin hangi koşullarda Ana Türkçede bir é sesinden geliştiği sorusuna yanıt verebilmenin güçlüğü olduğu (Poppe 1960: 102-106) konusuna değinildikten sonra Ana Türkçede çoğunluğu kapalı uzun e ile kurulan sözcük listesi verilmiştir. Ana Türkçede kısa /é/ ile kurulan ve i/e ile karşılanana sözcükler ise şunlardır: éb'acele etmek', ivedi 'çabuk davranma zorunluluğu, çabuk yapılan' <év- 'acele etmek', élt- 'iletmek', éşit'işitmek', kértü 'gerçek', séz- 'sezmek', yégirmi 'yirmi', yelin 'kısrak memesi', yér 'yer' (Ceylan 1991: 164).

21 AT hūr > ET ur-> ETT vur- 'vurmak' (Özek 2013: 651). 


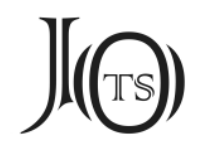

\subsubsection{1.}

\#y- ünsüz türemesi (sandide) görülür (Tekin 2003: 78). Ön seste (söz başında) /y/ türemesi: Kök. (Orh.) yıld- 'göndermek' < AT *id- , Kök. (Orh.) yllpagut 'yiğitler, alpler' < İT *ālppagut (Özek 2013: 655).

\subsubsection{Söz İçinde /y/ Türemesi}

Yan yana gelen iki ünlü arasındaki boşluğu doldurmak için kullanılan biricik ses (Pekacar-Erdem 2011: 231) /y/ türemesiyle bertaraf edilir; $y ı r(1)+y+a$ 'kuzeyde' (KT G1) vb. (Tekin 2003: 78).

\subsubsection{Söz Sonunda /y/ Türemesi}

Uzun /i / ünlüsü kısalırken alçalan diftong șeklinde iz bırakır: iniy[+gün+üm] 'erkek kardeşlerim' < *iniy <*ini: [krş. Yak. ini: 'erkek kardeş'] (Tekin 2003: 101).

\subsubsection{Diyalekt (ağız) görünümü /e/ ve /i/ Ünlü Genişlemesi}

eki, iki < AT *i:ki, daha sonra Uygur yazısında /e/ ünlüsü görülür ekinti 'ikinci’ (Erdal 2004: 52). Ünlü genişlemesi uzun ünlüyle alakalıdır (Tuna 1988: 275).

\subsubsection{Birincil Uzun Ünlü Kısalırken Ünlü Değişmesi}

Burada öndamaksıllaşma sonucu uyumdan çıkılma görülür.

1.5.4.1. /i:/ > /i/

tida 'tutarak' (KT K11) < *ti:d- 'engel olmak' (Tekin 2003: 50, 57).

1.5.4.2. /i:/ > /1:/

tıtin- 'yırtılmak' (IB 44) <*ti:tın- (Tekin 2003: 50).

\subsubsection{3. Ünlü İkizleşmesi}

\subsection{Diftong}

\subsection{Alçalan Diftong}

/i:/ > /iy/: iniy+gün 'erkek kardeşler’ < ini: (Tekin 2003: 58).

\subsection{Yükselen Diftong}

/ö/ > /üö/: üöz (Uyuk Turan yazıtı) <*ō̄z (Tekin 2003: 58). 


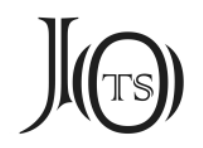

\subsubsection{Diğer Hecelerde Uzun Ünlü}

Çalışmanın hacmini artırmamak için birer örnekle yetinilmiştir.

\subsection{Söz Sonunda Uzun Ünlü}

$a^{a} t<-\bar{a}:$ ata ${ }^{a} s i z$ 'babasiz' (Uybat II) < *atā (Tuna 1988: 227).

\subsection{Kapalı Son Hecede Uzun Ünlü}

$/ \mathrm{u}^{\mathrm{u}} /</ \overline{\mathrm{u}} /$ : orku $n$ 'irmak adı, [Yüce Hun anlamında]' (Şine Usu Kuzey III 13) $<*$ orkūn (Tuna 1988: 227).

\subsection{Orta Hecede Uzun Ünlü}

/a $/$ < /ā/: ula ${ }^{a} t \imath$ 'ekleyerek' (Yazma IV) < *ulātı (Tuna 1988: 227).

\subsubsection{Eklerde Uzun Ünlü}

+/a $\mathrm{a}^{\mathrm{a}}$ + <+āa: başla $\mathrm{a}^{a}$ - 'başlayıp' (II 96) < *başlā- (Tuna 1988: 227).

\section{6.}

Uzun ünlüye sahip kapalı heceden sonra görülür: $/ \mathrm{o} /(1)</ \bar{o} / ;$ yokı bol- < *yōk bol- (Tekin 1975: 232). Aşağıda ünlü türemesinde de değinildi.

\section{2. Ünlü Benzeşmeleri}

\section{1.}

Derecesine göre yakın, yönüne göre ilerleyici benzeşme: ülüg 'kısmet, nasip, paya düşen' (BK D23) < üle-'paylaşmak' \{-(X)g\} fiilden isim yapım eki, ilerleyici yönde yakın ünlü benzeşmesi ile ülüg, 3. kişi iyelik eki $\{+(s) i\}$ art ünlülü sözcüklerde ünlü uyumuna girme eğilimindedir: sabın 'sözlerini' (T 22) < sab+in (KT K9), usın 'uykusunu' (T19) < *ū+sin. 1. kişi iyelik eki almış sözcüklerin belirli nesne durumlarında da benzeşme görülür: başımın 'başımı' < *başımin, vb.

\subsubsection{Uzak Benzeşme}

sök- 'diz çökmek' (KT D35) < çök- (Gürer 1990: 62) < AT *çöү-; antag < an1+täg (T29), iki sözcük arasında gerçekleşen ilerleyici uzak şekilde ünlü benzeşmesi, aşağıda gösterildiği üzere ünlü düşmesine de örnek: $b(i) r d(i) n$-yän 'güney tarafından' (T11) < *birdin yan, öydün-yän 'doğu tarafindan' (T I1) < öydün yan; erür barur 


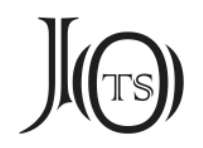

'(serbestçe) gelir gider, bağımsız' (KT K1, BK D29) < *erür barır, yatu kalur 'yata kalır' (T19) < *yatu kalır.

\subsubsection{Gerileyici Benzeşme}

Söz içindeki düz-dar ünlü kendisinden sonraki yuvarlak ünlünün etkisiyle çevre koşuluna uygun olarak gerilek bir biçimde yuvarlaklaşır; yaratunu uma'kendiniz düzene sokamamak' < yarat(1)nu uma- (BK D9), yütürüp ‘yitirip' (IB 24)

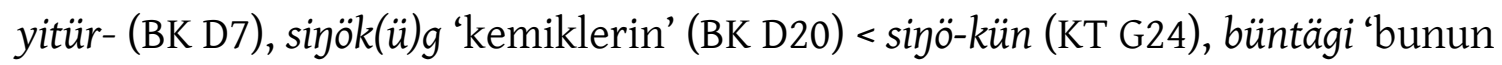
gibi' (T57)< *bunı tägi.

\subsection{Damak Uyumu (Assimilation Palatale 'Dil Benzeşmesi')}

Artlık-önlük, kalınlık incelik uyumudur. Damak uyumuna giren ekler:

\subsection{1.}

Olumlu sifat eki $\{+1 \mathrm{Xg}\} /\{+1 \mathrm{Xk}\}$ : baş+l(1)g 'mağrur' (KT D2), kinl(i)g 'mis kokulu' (BK K1) (Tekin 2003: 55).

\subsection{2.}

İkinci kişi teklik $\{-\mathrm{d}(\mathrm{X}) \mathrm{g}\} /\{-\mathrm{d}(\mathrm{X}) \mathrm{n}\}$ ve çokluk $\{-\mathrm{d}(\mathrm{X}) \mathrm{m}(\mathrm{X}) \mathrm{z}\} /\{-\mathrm{d}(\mathrm{X}) \mathrm{g}(\mathrm{X}) \mathrm{z}\}$ kesin geçmiş zaman ekleri: bar- $d($ ( $) g$ 'gittin' (BK D20), içik- $d(i) \eta$ ‘bağımlı oldun' (KTD 31); bir-t(i)m(i)z 'verdik' (KT D20), bar-d(i)g(i)z 'vardınız, gittiniz' (KT GD) (Tekin 2003: 55).

\subsection{3.}

Yer-yön bildirme eki $\{+\mathrm{D}(\mathrm{X}) \mathrm{n}\}$ : $k u r(1)+d \imath n$ 'batıda' (KT B1), bir+d(i)n+yän 'güney tarafından, güneyden' (T11) (Tekin 2003: 55).

\subsection{Dudak Uyumu (Assimilation Labiale 'Dudak Benzeşmesi')}

Yuvarlaklaşma, diğer bir ifadeyle Yakut, Altay ve Kırgız Türkçesinde bulunan dudak çekerliliği (labial atraction) ${ }^{22}$ Orhon yazıtlarında bir ağız (diyalekt) özelliği olarak görülmektedir: orto ‘orta’ (KT G2), törö ‘sözlü yasalar' (KT D1) (Gülsevin 1990: 61), olortokum ‘(tahta) oturduğum’ (BK D36).

22 Kırgız Türkçesinde yuvarlak dar /U/ hariç ekleşmede /o/ ve /ö/ görülmesi (Okçu 2019: 225). 


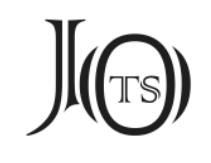

Belki günümüz Kırgız Türkçesinde gelişen ileri seviye dudak uyumunu hazırlama ve birinci hecenin dişında (ikinci hecede, nadiren üçüncü hecede de) yuvarlak ünlüyü bulundurma; bodun 'halk' (KT D26) < *bodun, buzdumuz 'bozguna uğrattık' (KT D31), ol(o)r- 'oturmak' (T8), olortum 'tahta oturdum' (KT D 26, vb) < *olordum, olortok 'tahta oturduğu' (KT D17), ötüntök 'arz ettiğim' (T15) < *ötündok, tunukuk 'Tunyukuk' (genel olarak) < tunyukuk (BK G14) < tun 'ilk' + yukuk 'vezir', uduztum 'sevkettim' (T15), uduzt[ok] 'sevketti' (KQ D1), yañdok 'dağıtılmış olanlar' (Tekin 2003: 68, 75, 76, 77), töpö 'tepe' > täpä (Erdal 2004: 94) [bk. /ä/ > /ö/,/p/ > /b/], boto 'deve yavrusu' (Aydın 2013: 39).

\subsection{1.}

Bağlama ünlüleri dudak uyumuna girer; Karluk+(u)g 'Karlukları' (KT K2), siyök+(ü)y ‘kemiklerin' (KT D24), totok+(u)g 'askeri valiyi' (KT D38) (Tekin 2003: 54).

\subsection{2.}

Dudak uyumuna (düzlük ve yuvarlaklık uyumuna) giren ekler: kinl(i)g 'mis kokulu' (BK K11), başl(1)g 'mağrur' (KT D2); muylug 'dertli' (IB 22), küçlüg 'güçlük' (Tekin 2003: 55).

\subsection{Dudak Uyumuna Giren Ekler}

\subsection{1.}

Olumlu sifat eki \{+lXg\}: muplug 'dertli' (IB 22), küçlüg 'güçlü' (IB3), top(u)lguluk ‘delmek için' (T13), üzg(ü)lük ‘kırmak için' (T14) (Tekin 2003: 55), özlük ‘kişiye ait, şahsi' (Küli Çor D3) < öz 'kendi', yazuklug 'kabahatli' (BK D2) (Tekin 2003: 259).

2.4.2. Birinci teklik $\{-\mathrm{t}(\mathrm{X}) \mathrm{m}\}$ ve Çokluk $\{-\mathrm{tXm}(\mathrm{X}) \mathrm{z}\}$ Kesin Geçmiş Zaman Ekleri

buz-d(u)m 'bozguna uğrattım' (BK D24), kälür-t(ü)m 'getirdim' (KT G11), süg(ü)ş-d(ü)m(ü)z ‘savaştık' (BK D28) (Tekin 2003: 55).

\subsubsection{Yer-Yön Bildirme Eki $\{+\mathrm{D}(\mathrm{X}) \mathrm{n}\}$}

öy+d(ü)n+yan ‘doğu tarafından’ (T11) (Tekin 2003: 55). 


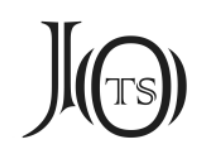

\subsection{4. İsimden İsim Yapım Eki $\{+(\mathrm{X})$ ş\}}

öd+üş 'tam gün 24 saat' (BK GD) < öd 'zaman' (KT G1), ur-uş 'savaş' (Ongin 10) $<$ ur- 'vurmak, dövmek' (KT D36).

\subsubsection{Fiilden İsim Yapım Eki $\{-(\mathrm{X}) \mathrm{k}\}$}

közün-ük 'çadır penceresi' (IB 27) < közün- 'görünmek', tor-uk 'zayıf' (KT D9) < tor- 'zayıflamak, bitap düşmek' (KT G9), yaz-uk' günah' (BK D36) < yaz- 'yanılmak, hata etmek', krş. yazın- 'yanılmak, hata etmek' (BK D17), yazuklug 'kabahatli’ (MQ D2).

\subsubsection{Fiilden İsim Yapım Eki $\{-(\mathrm{X}) \mathrm{m}\}$}

öl-üm ‘ölüm' (IB 13) < öl- ‘ölmek’ (KT K10).

\subsubsection{Fiilden İsim Yapım Eki $\{-(\mathrm{X}) \mathrm{n}\}$}

bul-un 'tutsak, esir' (Küli Çor B5) < bul- 'elde etmek, ele geçirmek' (KT D31).

\subsubsection{Fiilden İsim Yapım Eki $\{-(\mathrm{X})$ ş\}}

ur-uş 'savaş' (Ongin 10) < ur- 'vurmak, dövmek' (KT D36).

\subsubsection{Ettirgen Çatı Eki \{-gUr\}}

od-gur- 'uyandırmak' (IB 20) < *od- 'uyanmak', krş. Uygurca odug 'uyanık', odug sak 'uyanık, dikkatli' [ikileme odug sak 'uykusu hafif kimse'] (Ölmez 1998: 35).

\subsection{9. İkinci Çokluk Kişi İyelik Eki $\{+\mathrm{XyXz}\}$}

tay+gun+ujuz (KT GD) 'tay (gibi oğul)larınız'.

2.4.10. Ünlü Türemesi de Sayılabilen Bağlama Ünlülerinin Dudak Uyumuna Girmesi

Karluh+(u)g ‘Karlukları' (KT K2), ög+(ü)m ‘annem' (IB 58), sinök+(ü) $\eta$ ‘kemiklerin’ (KT D24), ok+(u)n ‘ok ile’ (KT D33) (Tekin 2003: 54).

\section{Uyumsuzluk}

Alınma kelimelerde görülür: ançola- 'sunmak, takdim etmek' (KT D32) < Çince an chang + Türkçe \{+1A-\} (Ölmez 1995: 228). 


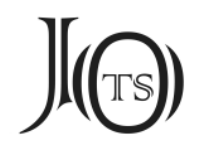

\subsection{Damak (Artlık-Önlük) Uyumuna Girmeyen Ekler}

\subsection{1. Üçüncü Kişi İyelik $\operatorname{Eki}^{23}\{+(s) i\}$ 1. ve 2. Teklik Kişi İyelik Ekinden Sonra Belirtme Eki \{+in\}}

kurugsak+(l)m+in 'kursağımı' (IB 8) ve kan+(l) $n+i n$ 'hanını' (T3).

\subsection{2. Ön Damaksıllaşmayla Uyumdan Çıkma}

Herhangi bir seslemdeki düz-dar art ünlü damaksıllaşarak ünlü uyumundan çıkar: bulmay(i)n ‘bulmayıp’ < *bulmayın, vd. (Tekin 2003: 50). Yukarıda birincil uzun ünlü maddesi işlenirken /i:/ > /1/ değişiminde de bu duruma değinildi.

\subsubsection{Geçmiş Zaman Eki \{-miş\}}

Bu ek artlık-önlülük uyumuna girmez: kagans(l)ramiş 'hakansız bırakmış' (Tekin 2003: 50, 53).

\subsection{Dudak Uyumuna (Düzlük-Yuvarlaklık) Uymayan Ekler}

\subsection{1. İlgi/Tamlama Eki ve 3.2.2. Üçüncü Teklik Kişi İyelik Eki \{+(s)i(n)+\}}

türük bodun+ıø ‘Türk halkının’ [tamlama ekinin yardımcı ünlüsü], eçüm apam törü+sin+çe 'atalarımın dedelerimin töresince' vb. yuvarlak ünlülü ekler (Ata 2011: 86); kazgantok+in 'kazandığı' (T55) <*kazgandok.

\subsubsection{Yön Eki}

ortosinaru 'ortasına doğru' (KT G2) < *orto+sin+garu (Tekin 2003: 77); kirü 'batı' (<*ki [arka, sonra] \{+rü\} [yön gösterme eki]) (BK D3).

23 3. Teklik kişi iyelik eki $\{+(s) I(n)\}$ şeklinden sonra belirtme durumu varsa bu fonksiyon $\{+\varnothing\}$ accusatie ile $\{+(s) i(n)+\varnothing\}$ olarak gösterilebilir; sab+in+Ø ‘sözlerini’; Belirli nesne durumundaki isimlerde $\{+(s) I n\}$ eki tarihi metinlerde 3. teklik iyelik eki almış belirli nesne durumundaki adlar üzerinde, yükleme durumu olarak bilinen $\{+(\mathrm{I}) g\},\{+I\},\{+n I\}$ şekilleri pek kullanılmamaktadır. Geçişli fiillerle kullanılan iyelikli isimlerin sonuna çoğunlukla $\{+n\}$ eklenmiştir. eçi+sin bilmez erti (KT D21) 'Ağabeyini bilmezdi.' il+in törü+sin ança kazgantı (KT D31) ‘ilini töresini böylece kazandı.' kan+in ölürtümiz (T1 K4) 'Kağanını öldürdük.' sü+sin sançdımız (KT K6) 'Askerlerini mızrakladık.' yabgu+sin şad+in anta ölürti (T2 B6) 'Yabgusunu, şadını orada öldürdü.' 'Türk dilinde üçüncü şahıs iyelik eki, diğer iyelik ekleri gibi zamir kaynaklıdır. Ana Altaycada öncül konumda bulunan zamir+ilgi hâli (*in+in) kuruluşundaki iyelik zamiri, gramerleşerek soncul konuma geçmiş ve iyelik ekine [*in+in>+(s)I(n)] dönüşmüş olmalıdır.' (Başdaş 2014: 152-158). 


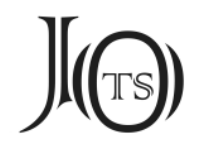

3.2.4. Kesin Geçmiş Zaman 3. Teklik Kişi Eki \{-DX\}:

uçdı ‘uçtu’ (KT KD), ölti 'öldü’ (KT D33) (Tekin 2003: 55).

\subsubsection{Sifat-Fiil Ekleri}

\subsubsection{Düz-Dar Ünlülü Sıfat-Fiil Ekleri}

\subsection{Geçmiş Zaman Sıfat-Fiil Eki \{-miş\}}

boşgurm(i)ş 'öğretmiş̧' (KT D13) ve bolmiş 'olmuş' (KT D21) (Tekin 2003: 57). Bu ek artlık-önlülük uyumuna girmez (Tekin 2003: 50, 53).

\subsection{Gelecek Zaman Sifat-Fiil Eki \{-sik\}}

ol(o)rs(1)k(1)m ‘oturasım' (T22) (Tekin 2003: 56).

\subsubsection{Yuvarlak-Dar Ünlülü Sıfat-Fiil Ekleri}

\subsubsection{SIfat-Fiil Eki \{-GUÇI\}}

anta ay-guçl+sı yeme ben ök ertim (T49) ‘o sırada, (onun) sözcüsü de bizzat ben idim', bitig taş it-güçi (KT K13) 'yazıt yapımcısı'.

\subsubsection{Kesin Geçmiş Zaman Sıfat-Fiil Eki \{-DUk\}:}

türük bodun illedük ilin ıçgınu ıdmış (KT D6) 'Türk halkı kurduğu devletini elinden çıkarıvermiş', tenri yarlıkadukın üçün (KT G9) ‘Tanrı buyurduğu için’.

\subsection{Yuvarlak Ünlülü Zarf-Fiil Ekleri}

\subsubsection{Zarf-Fiil Eki $\{$-yU\}}

keyik yiyü tabışgan yiyü olurur ertimiz (T8) 'Yabanî hayvan yiyerek, tavşan yiyerek oturuyorduk', köl tigin yadagin oplayu tegdi (KT D32) 'Prens Köl yayan olarak atılip saldırdı'.

\subsection{Olumsuz Sifat Eki $\{+$ sIz $\}$}

buy+SIz 'pek çok' (Açura 7) (Tekin 2003: 55).

\subsection{Addan Eylem Türeten Ek $\{+$ sIrA- $\}$}

ur(u)gs(l)rat- 'dölsüz bırakmak' (KT D10) (Tekin 2003: 56). 


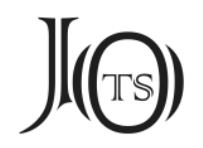

\subsection{Bağlama Eki $\{+1 \mathrm{II}\}$}

tün+li kün+li 'gece gündüz' (KT GD) (Tekin 2003: 56).

\subsection{Belirli Nesne Eki $\{+n I\}$}

$k u+n l$ 'general+i, Ku'yu' (T9) (Tekin 2003: 56).

\subsection{Pekiştirme Eki \{+gIl\}}

urg(i)l ‘mutlaka koy!' (T4) (Tekin 2003: 56).

\subsection{Aitlik Sifat Eki $\{+\mathrm{GI}\}$}

çölgi ‘bozkıradaki' (T23), bod(u)nkı 'düşman halkınınki' (Tar. B5) (Tekin 2003: $56)$.

\subsection{Nitelik Ad1 Yapan Ek $\{+G U\}$}

baş+gu 'alnı beyaz akıtmalı' (KT D37) < baş 'baş' (BK D25), ed+gü 'iyi, yarar, kazanç' (BK D19) < ed ${ }^{24}$ 'mal, değerli şey', negü+de 'nerede' (IB 24) sözcüğünde $\{+\mathrm{dA}\}$ bulunma durumu eki, negü < ne 'ne, hangi' (BK D9).

\subsection{4. Çatı Ekleri}

\subsubsection{Ettirgen Çatı Eki \{-GUr-\}}

tir-gür- 'diriltmek, canlandırmak' (KT D29) < tir- 'yaşamak'.

\subsubsection{Ettirgen Çatı Eki \{-Ur-\}}

yoja-ş-ur- 'karşılıklı iftira ettirmek, kışkırtmak' (KT D6) < yoyaş- 'birbirini tahrik etmek, iftira etmek' < yoya- 'iftira etmek', krş. yoya\{r\}smak 'iftiralaşma' Altun Yaruk 6. kitap 687 (Zengin-Yaman 2018: 210).

\subsubsection{Ettirgen Çatı ve Pekiştirme Eki \{-Ut-\}}

yüz-üt- 'yüzdürmek' (BK D30) < yüz- 'yüzmek', tök-üt- 'dökmek, akıtmak' (T52) < tök- 'dökmek' (Ata 2017a: Ünite 2).

${ }^{24}$ Bu kökten türetilmiş diğer kelimeler: edsiz 'faydasız', edlig 'değerli, kıymetli', edger- 'gelişmek', edgü 'iyi', edgüti 'iyice' < ed 'mal, değerli şey'. 


\section{J(৫)}

\subsubsection{Ettirgen Çatı Eki \{-tUr-\}}

bin-tür- 'bindirmek' (T25) < bin- 'binmek' (KT K2), ir-tür- 'erdirmek, eriştirmek' (KT D40) < ir- er- 'erişmek, varmak', kon-tur- 'kondurmak, yerleştirmek' (KT D11) < kon- 'konmak, yerleşmek' (KT G7) < ko- 'koymak', yan-tur- 'döndürmek, geri çevirmek' (KT K11) < yan- 'dönmek' (KT D28).

\subsubsection{Ettirgen Çatı Eki \{-tUr-\}}

kel-ür- 'getirmek' (T53) < kel- 'gelmek' (BK D31), öl-ür- 'öldürmek' (KT D40) < öl- 'ölmek' (KT K4), teg-ür- 'eriştirmek, vardırmak' (T 47) < teg- 'değmek' (KT K2), tüş-ür- 'indirmek' (T27) < tüş- 'düşmek, inmek' (KT K4).

\subsubsection{Ettirgen Çatı Eki $\{-U z-\}$}

tut-uz- 'tutturmak, yakalatmak' (KT D38) < tut- 'tutmak, yakalamak' (KT G8), ud-uz- 'yönlendirmek, önderlik etmek' (T15) < ud- 'takip etmek'.

\subsection{Zarf Eki $\{+\mathrm{ti}\}$}

edgüti 'iyice’ (KT G2) (Tekin 2003: 57).

\subsection{Topluluk Ad1 Yapan Ek \{+gUn\}}

iniy+gün+üm (KT G1) 'erkek kardeşlerim', kelinünüm (KT K9) 'gelinlerim' $<$ kelin+gün, tay+gun (KT GD) 'tay gibi oğullar'.

\subsection{9. Üçüncü Teklik Kişi Emir Eki \{-zUn\}}

türük bodun yok bolma-zun bodun bolçun tiyin ... (KT D11) 'Türk halkı yok olmasin, (yeniden) halk olsun diye ...' .

\section{4. Ünlü Nöbetleşmesi}

/a/ /1/ /u/: alpagu (KT K7) yllpagut 'yiğit savaşçılar' (BK D31) (Tekin 2003: 57), tatıq tutıq tutuq 'pas, kir' (Kononov 1980: 73).

/e/,/ä/ /i/: ben 'ben' (T1) bini 'beni' (T10), sen 'den' (KT G8) sini 'seni' (T10), erser 'ise' (KT G7) irser (KT G13), eçi içi 'ağabey' (BK D20) (Ata 2011: 87, 90).

/é/ / i/: (e)lt- (T32) ilt- (BK D9) 'iletmek, sevk etmek' (Tekin 2003: 47).

/i/ /1/: biç- bıç- 'biçemek, kesmek' (Tekin 2003: 240; Kononov 1980: 73). 


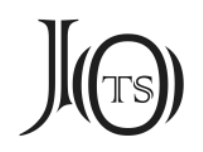

/i/ /ü/: köpik köpük 'köpük' (IB 20) (Tekin 2003: 248; Kononov 1980: 73).

/1/ /u/: toql- toqu- 'dövmek' (Tekin 2003: 255; Kononov 1980: 73).

/ö/ /ü/: sök- sük- 'sövmek'(Kononov 1980: 73) < sög- < *sö- 'söz söylemek'.

/o/ /u/ /1/: sıgun 'geyik' (BK B5) (Tekin 2003: 252) sogun sugun (Kononov 1980: 73).

\section{2. Öndamaksıllaşma}

İlk hecede: Çevre şartı itibariyle ilk hecenin /1/ ünlüsü komşu inceltici ünsüzlerin tesiriyle öndamaksıllaşma temayülü gösterir.

\subsection{1.}

[b]ıç- (BK G12) biç- 'biçmek' (IB 37), ir+in 'kuzeyini' (MQ D11), ir+intä 'kuzeyinde' (MQ D11) yır 'kuzey' vb. (Tekin 2003: 57).

\subsection{2. İkinci Hecede}

Art /1/ ünlüsünün öndamaksılaşması yer zarfı yırya 'kuzeyde' sözcüğünün ikinci hecesinde de gerçekleşmiş olabilir: y(l)ryä (OF 2) < yırya (KT G1) (Tekin 2003: 57).

\subsection{Artdamaksıllaşma}

/ä/ > /a/: Orhon sägün < Çince tsiangkün 'general' > Yenisey saynun (Tekin 2003: 47).

\section{5. Ünlü Korunmas1}

Söz içinde dar ünlünün daralıp düşme ve genişleyerek ünlü değişmesine uğramadan korunması: türük (BK D1), buz- 'bozmak, bozguna uğratmak' (KT D31), tug- 'doğmak, (güneş için) doğmak' (KT G2).

\section{6. Ünlü Türemesi}

\section{1. Ön Seste (Söz Başında) Ünlü Türemesi}

ulu 'Ejderha (y1l adı)' (Tar. B2) < Çince lung 'ejderha' (Tekin 2003: 62). 


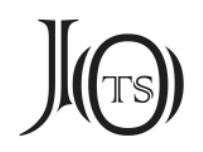

6.2. İç Seste (Söz İçinde) Ünlü Türemesi

\subsection{1.Ünsüz Çiftleri Arasında Dar Ünlü Türemesi}

/pr/, /gg/, /ys/, /çr/, /lg/, /lK/ ünsüz çiftleri arasında dar ünlünün türediği görülür. pur(u)m 'Roma, Bizans' (KT D4) < Part. ${ }^{25}$ Frum, diğer örnekler için bk. (Tekin 2003: 62), bölön 'bakan, vekil, yüksek görevli' < Tib. blon (Tekin 2003: 241).

\subsubsection{Ekleşme Sirasında Dar Ünlü Türemesi}

Söyleyiş zorluğunu gidermek için ortaya çımış bir ses hadisesi olduğu, kur1+garu sözcüğünde, tıpkı ili+gerü sözcüğünde olduğu gibi bir /i/ türemesinin söz konusu olduğu düşünülmektedir; kurı+garu < *kur+garu (Toker 2013: 8).

\subsection{Söz Sonunda Ünlü Türemesi}

Uzun ünlüye sahip kapalı heceden sonra görülür: yokı bol-<* yōk bol- (Tekin 1975: 232).

\section{7. Ünlü Düşmesi (Dar Ünlünün Düşmesi)}

Daha çok dar ünlü düşe de nadiren değişik örnekler çıkabilir: biçin 'maymun, yıl adı' (KT KD) < Çin. *fei-shen (Ölmez 1997: 179).

\section{1. $/ \mathrm{u} />/ \varnothing /$}

bulna- '(düşmanın) etrafını sarmak, tutsak etmek' < bulun+a- (Clauson 1972: 344a) Kök. bulna- '(düşmanın) etrafını sarmak, tutsak etmek' oglın kişisin bulna[...] 'oğlunu, karısını esir edip [...] (Ih B 5) (Demirci 2010: 131) < bulun 'esir, tutsak' . kamşa- 'sarsılmak' < *kamış+a- (Clauson 1972: 629a) Kök. kamşa- 'sarsılmak' (e)çim k(a)g(a)n ili k(a)mş(a)g boltukınta 'amcam kağanın ülkesi sarsıldığında' (KT K3) (Demirci 2010: 132). sıgta- 'ağlamak, feryat figan ederek ağlamak' < sıgıt+a- (Clauson 1972: 807a) Kök. sıgta- 'ağlamak, feryat figan ederek ağlamak' bunça bod(u)n $k(e) l(i) p(e) n$ sıgtam(1)ş ‘Bunca millet gelerek ağlamış’ (KT D4) (Demirci 2010: 137) < sıgıt 'ağlama, ağlayış'. oglan (KT G1) < ogul 'evlat' + \{+An\} 'çokluk eki', ünlüyle başlayan bir ek alındığında ikinci hecede (söz içinde) ünlü düşer ve orta hece düş-

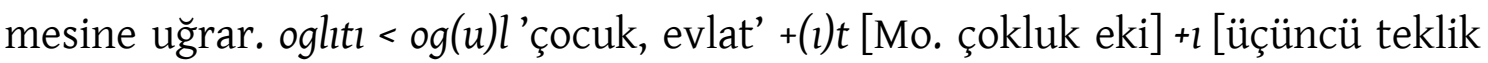

25 Partça 'Arsasid Pehlevicesi' (MÖ 248-224) İran'ın kuzeybatısı ve Horasan'ın büyük bir kısmını içine dâhil eden Part ülkesinin kaybolmuş bir Kuzeybatı İranî dilidir. 


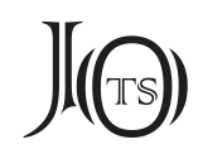

kişi iyelik eki], kubran- < kubura- 'toplanmak' (Tekin 2003: 248), ogl+... < ogll < ogul [beglik urı ogln kul bolt1] (BK 10), yagru 'yakın' < *yagu-r-u (Erdal 2004: 97), ogrı 'hirsiz' (IB 16) (Tekin 2003: 250) < ogur+la- (Erdal 2004: 98).

\section{2. $/ \ddot{\mathrm{u}} />/ \varnothing /$}

türk türük (Tekin 2003: 256) <*törü-k (Blažek 2019: 135). Sonra Kazak Türkçesinde türik şeklinde görülecektir. Türk < türük < törük < törü- < tör < *törr 'evde (hakanın çadırında) - dört köşeden oluşan, törelerin (dört bir tarafa gönderilen yasaların) konuşulduğu - onur yeri' (Blažek 2019: 136).

\section{3. $/ 1 />/ \varnothing /$}

antag < an1+täg 'iki sözcük arasında gerçekleşen ilerleyici ünlü benzeşmesi' (T29) (Tekin 2003: 60), agrt- 'hastalanmak, ağrımak' <agır+1-, Kök. agr1- 'hastalanmak' ul(u)g ogl(u)m (a)gr(l)p yok bolça 'büyük oğlum hastalanıp ölünce' (BK G9) (Demirci 2010: 143), kamşat- 'sarsılmak, sendelemek' < kamşa-t- < kamış+a- < kam-1-ş (Erdal 1991: 774) Kök. kamşat- 'sarsılmak, sendelemek' bod(u)n(a)d(a)k k(a)mş(a)tdl 'milletin ayağı sendeledi' (KT K7) (Demirci 2010: 312), adrl- 'ayrılmak' < *ad-(1)r(1)1- (Erdal 1991: 651) Kök. adrl- 'ayrilmak' (T B2) bo y(é)r(i)yde sub(u)yda (a) $\operatorname{dr}(\mathrm{l}) \operatorname{lm}(a) s(a) r$ 'Bu yerinden ve suyundan ayrilmasa' (BK K13) (Demirci 2010: 338), kazgan- 'kazanmak' < *kaz-l-k+a-n- (Erdal 1991: 604) Kök. kazgan- 'kazanmak' k(i)mke il(i)g k(a)zg(a)nur m(e)n 'Kime ülke kazanıyorum' (KT D9) (Demirci 2010: 139), kubra- 'derlemek, toplamak' < kubura- (Tekin 2003: 248) < *qop qub+lr+a-< *qop 'çok' < *qo- 'koymak, örmek' (Kononov 1980: 118), adrl- 'ayrılmak' < *hadır(Choi 2019: 82), yabrt- 'bozguna uğramak' < *yabır > yabız 'yavuz, kötü' (Choi 2019: 253), kork- 'korkmak' < *kor1-k- (Gülensoy 2007: 542) < kor1- (Choi 2019: 253), kork'korkmak' < korık- (Erdal 2004: 97).

\section{4. $/ \mathrm{i} />/ \varnothing /$}

\subsubsection{Söz İçinde Ünlü Düşmesi}

ägri 'eğri' < ägir- 'kuşatmak, çevirmek' (KT G6) (Choi 2019: 237), balbal balbar 'öldürülen düşmanın taş heykeli' (Tuva III 4) < Mo. barimal (Tekin 2003: 239), Likäg 'kişi adı' (KT K12) < Çin. Lu xiang (Ölmez 1999: 62), täglük (IB 24) (Tekin 2003: 254) > *tägil+ök 'kör' (Erdal 2004: 87), mäylä- '(vahşi hayvan) ava çıkmak, avlanmak' (IB 49) [mäy 'yiyecek' < *mäni] (Tekin 2003: 250) < mänilä- (Erdal 2004: 94). 


\section{$J(\Theta)$}

\subsubsection{Son Seste Ünlü Düşmesi}

kül çor (BK G13) < küli çor (KÇ B6) (Tekin 2003: 62).

\section{5. $a \#>\varnothing \#$}

Makaraç 'özel ad' (KT G13) < Skr. Mahārāja (Ölmez 1999: 64).

\section{8. Ünlü Çatışması}

öl-ür-teçik [gelecek zaman eki \{-tAçI\} + pekiştirme edatı ök], yine kagan+laduk [-duk <*-di+ök], buçegü [< bu üç+egü] (Ata 2011: 184164 108), nälök 'niçin' (IB 57) (Tekin 2003: 250) <*ne+gü ol+ök $[\{+g U l\}<\{+g U\}+o l](E r d a l ~ 2004: 125)$ [ne soru sözcüğü üzerine Orhon Türkçesine mahsus $\{-g U\}$ soru edat1 $]^{26}$ veya < ne+(A)gU+lXk (Erdal 2004: 60 213) ya da nälök <ne+le ök. ${ }^{27}$

\section{Yardımcı Sesin Ekleşme Sırasında Tezahürü}

\section{1.}

Ekte /a/ kalın-geniş ünlüsünün yardımcı ses olarak görülmesi: Emir eki \{(A)lIm\}: yort-lım ‘yürüyelim' (T29), yok kış-alım 'yok edelim' (T11) (Ata 2011: 149).

\section{2 .}

Ekte, dar-ince /i/, dar-kalın /1/ ünlüsünün yardımcı ses olarak görülmesi: Şimdiki zaman eylem sıfatının \{-(I)gmA\} eki ile kurulması: bar-ıgma 'giden', käligmä 'gelen', biti-gmä 'yazan', vb. (Tekin 2003: 17).

\section{Hece Düşmesi/Selem Yitimi}

oglan (KT G1) < ogul 'evlat' + an 'çokluk eki', ünlüyle başlayan bir ek alındığında ikinci hecede (söz içinde) ünlü düşer ve orta hece düşmesine uğrar. Yukarıda dar ünlü düşmesinde de geçmişti. buyruk 'kumandan' < buyur-uk, fiilden isim yapım ekini üzerine alınca ünlü düşerek hece düşmesi olur (KT G1), adrl- 'ayrılmak' (T B2) < *ad- 'ayrı olmak' (Bu sözcüğün kökü, adın 'başka, diğer' sözcüğünden dolay1 *ad-olmalı.) -(ı)r'ayrılmak' [ettirgenlik eki: orta hece düşmesiyle adır] -(ı)l [edilgenlik eki] -tı [3. teklik kişi belirli geçmiş zaman eki], nälök 'niçin' (IB

26 mU, Orhon Türkçesi metini T yazıtında iki kez saptanmıştır (Çetin 2008: 311).

27 ne+le+ök (Hacieminoğlu 1992: 280-281), Irk Bitig ve Manihaica I Anhang metinlerde sözcüğün negülük'ten gelmediği nele ök’ten geldiği düşünülmektedir (Barutçu 1992: 74-75). 


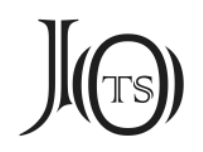

57) (Tekin 2003: 250) < *ne+gü ol+ök $[\{+g U l\}<\{+g U\}+o l]($ Erdal 2004: 125) [ne soru sözcüğü üzerine Orhon Türkçesine mahsus $\{g U\}$ soru edat1 $]^{28}$ veya < ne+(A)gU+lXk (Erdal 2004: 60 213) ya da nälök < ne+le ök. Bk. yukarıda ünlü çatışması, aşağıda erime, hece kaynaşması.

Aşağıda ünsüzler başlığı altında da hece düşmesinden söz edildi.

\section{Hece Kaynaşması}

Türkçe sözcüklerde karşılaşılan ses olaylarından biri ses düşmesi/hece kaynaşması olayıdır. Kaynaşma, ünlü birleşmesi, büzülme, derilme, ünlü aşınması, vokal birleşmesi, ses düşmesi/ünlü düşmesi gibi adlandırmalar da vardır (Ersoy 2017: 36). bödkä 'bu zamanda’ (BK K1, 8, D2); (KT G11) < bu ödkä (KT G1) vd. (Tekin 2003: 63), öl-ür-teçik [gelecek zaman eki -teçi + pekiştirme edatı ök], yine kağan+la-duk [-duk < *-di+ök], buçegü [< bu üç+egü] (Ata 2011: 184164 108), nälök 'niçin' (IB 57) (Tekin 2003: 250) yukarıda geçen izah göz ardı edilirse (Erdal 2004: 60 213) nälök <ne+le ök (Barutçu 1992: 74).

\section{2. Ünlü Değişmeleri}

\section{1. Ünlü Kısalmas1}

\subsection{1. $/ * \bar{a} />/ \mathrm{a} /$}

sansız 'sayısız, sınırsız, çok' < *sān 'sayı' < *sā- 'saymak'; kalısız 'tümüyle, tamamıla, artıksız, eksiksiz' < *kālı 'kalıntı, artık', aşsız 'yiyeceksiz, yemeksiz' < āş 'yiyecek, yemek'; kal- 'kalmak' < kāl- 'kalmak, umutsuz durumda kalmak' (Tekin 2003: 245),

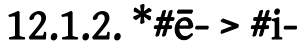

idisiz ‘sahipsiz’ < *ēdi ‘sahip’ (Soydan 2017: 881, 875).

\subsection{3. $/ *_{\mathrm{i}} / />/ \mathrm{i} /$}

yir 'yer, memleket' < *yi:r, iş 'iş’ < *i:ş (Choi 2019: 127 151).

\footnotetext{
${ }^{28}$ mU, Orhon Türkçesi metini T yazıtında iki kez saptanmıştır (Çetin 2008: 311).
} 


\section{J(৫)}

12.1.4. $/{ }^{*} \bar{o} />/ o /$

bol- 'var olmak' (IB 19) (Tekin 2003: 241) < *bōl- (Choi 2019: 93), on '10, on'< *ōn (Choi 2019: 283).

\subsection{5. $/ * \bar{\partial} />/ \ddot{\partial} /$}

kök 'mavi' < *kö:k [iç seste iki hecelileşmeyle Çuv.'da kı̌vak] (Choi 2019: 65).

12.1.5. $/ \overline{\mathrm{u}} />/ \mathrm{u} /$

buka 'boğa' < būka (Tekin 2003: 241).

\subsection{6. $/ * \overline{\mathrm{u}} />/ \mathrm{u} /$}

Ünlü kalınlaşması ve ünlü kısalması: kulkak 'kulak' (BK K60/10-12) < *külkak [ < *kü̈+l- > kul- 'işitmek' (Gülensoy 2007: 565)] krş. kü 'ses, haber; ün, şöhret' < *kü.

\subsection{7. $/ * \overline{\mathrm{u}} />/ \ddot{\mathrm{u}} /$}

yüz 'çehre' < *yüz (Choi 2019: 130).

\subsection{8. $/ * \overline{\mathrm{u}} />\mathrm{i}$}

bişük 'akraba' (KT G6) < *bǖşük [<*bül <*pöl²] >> MKo. p’ar (Choi 2019: 96).

\section{3. Ünlü Daralması}

\section{1. $/ \mathrm{a} />/ 1 /$}

$k(a) p($ l)gka 'kapıya' (KT G1) < kapa-g+ka (kapa- 'örtmek' \{-g\} [ikinci hecede ünlü daralmasıyla fiilden isim yapım eki], \{+kA\} [yönelme durum eki]).

\section{2. $/ \mathrm{a} />/ \mathrm{o} /$}

ançola- 'sunmak, takdim etmek' (KT D32) < Çin. an chang + Tü. $\{+1 \mathrm{~A}-\}$ (Ölmez 1995: 228).

\section{3. \#é- > \#i-}

ini 'erkek kardeş' < *éni (Choi 2019: 148). 


\section{4. /\#o-/ > /\#u-/}

$\mathrm{ok}^{29}+(\mathrm{u}) \mathrm{l} / \mathrm{r} / \mathrm{z} /$ ş [aşağıda l > ş, ve $\mathrm{r}>\mathrm{z}$ maddesine bk.] > uguş 'soy-sop' < *oguş < ogul, ogl+an 'evlat' < ogul+an (KT G), kunçuy 'prenses' < Çin. gong zhu (Ölmez 1999: 59), kung çu 'imparatorun kızı' (Tekin 2003: 249).

\section{5. /ö/ > / ̈u/}

küzyü 'ayna' < *küz < köz (Tekin 2003: 249) [<*kör+i-nü, $(r>$ z ve i > Ø, ö > ü)], kürlüg 'hilekâr' < *Mo. ? körlüg (Ölmez 1999: 61), täglük (IB 24) (Tekin 2003: 254)< *tägil-ök 'kör' (Erdal 2004: 87).

\section{6. /ö/ > /i/}

ölürteçik'öldürecektir' (T G11) < öl-ür-teçi+ök < ölür- 'öldürmek' < öl- 'ölmek' ür [ettirgenlik eki] -teçik [-teçi gelecek zaman eki ve ök pekiştirme edatının birleşmesi ile oluşmuş].

\section{4. Ünlü Yuvarlaklaşması}

\subsection{Düz-Dar Ünlünün Genişleyip Yuvarlaklaşması}

/ *i/ > /o/: toruk 'zaylf' < tor-'zayıflamak, bitap düşmek' < *tïr (Soydan 2017: 877) ‘en uç kısım' [Tuvacada tıră̆, Ortagüney Özbekçede tirnok] (Demir 2014: 141).

\section{2. Ünlü Genişlemesi ve Ünlü Yuvarlaklaşması}

/ï/ > /o/: tonsiz 'giyeceksiz, fakir' < ton 'elbise' < tïn 'üst giyimi’ (Soydan 2017: $881)$.

\section{3. $/ 1 />/ \mathrm{u} /$}

bult 'bulut' (IB 52) (Tekin 2003: 241) < *bilit (Erdal 2004: 94).

29 Buradaki ok sadece 'yarlığ' ve 'payza' (Özyetkin 2005: 30) yani tamamen bir 'tevcih-nâme', bir 'yetki belgesi' durumundadır ve tabiiyeti ifade eder (Aydemir 2009: 58). Hakana tabi olmak ok alametiyle yapılmış buradan da boy anlamı ve ok+1- fiili de türetilmiştir. 


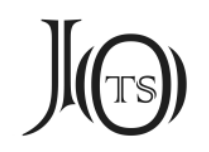

\subsection{Dar Ünlü Yuvarlaklaşması}

\subsection{1. /i/ > /ü/}

Künüy 'iramak adı' (Tar. B5) < Mo. Huni, Huniyn (Tekin 2003: 249), büt- '(arzusu, dileği) yerine gelmek, kanmak, doymak' (Açura 12) (Tekin 2003: 242) < *bit‘tamamlanmak, kemale ermek' (Erdal 2004: 94).

14.3.2. -I\# >-U\#

$m U$ 'soru edat1' < *mI (Erdal 2004: 94).

\subsection{Yar1 Geniş Düz Ünlünün Yuvarlaklaşması /ä\#/ > /ö\#/}

töpö 'tepe' < *täpä (Erdal 2004: 94).

\subsection{Geniş Ünlünün Dar-Yuvarlak Ünlü Olarak Değişmesi}

/a/ > /u/: bodun 'halk' (Tekin 2003: 241) < *boda+n [Mo. boda, \{+(A)n\} çokluk eki] (Erdal 2004: 99).

\section{5. Ünlü kalınlaşması}

\section{1. $/ \mathrm{i} />/ 1 /$}

sıgıt 'ağlama' < sigit (Choi 2019: 225), yılan (IB 8) (Tekin 2003: 259) « A. Alt.*ńilon, aşağıda /ń/ > /y/ ünsüz değişmesinde de izah edildi.

\section{6. Ünlü incelmesi}

\section{1. $/ \mathrm{u} />/ \ddot{\mathrm{u}} /$}

Künüy 'rramak adı' (Tar. B5) < Mo. Huni, Huniyn (Tekin 2003: 249).

16.2. /o/ > /ö/

bölön 'bakan, vekil, yüksek görevli’ < Tib. blon (Tekin 2003: 241).

\section{3. Ünlü İncelmesiyle Ünlü Değişimi}

Önce diş ünsüzü /t/'nin inceltici etkisiyle /1/ > /i/, sonra ilerlek benzeşmeyle /+a\#/ > /+e\#/ ünlü incelmesi olup kalın sıradan ince sıraya geçilmiştir; tile'dilemek, istemek' < tıl+a- , Kök. tile- 'dilemek, istemek' yérçi tiledim 'Kılavuz istedim' (T6) (Demirci 2010: 139). 


\section{J(৫)}

\section{7. Ünlü Düzleşmesi}

\section{1. $/ \mathrm{o} />/ \mathrm{a} /$}

yılan (IB 8) (Tekin 2003: 259) <* *ńilon, bk. /o/ > /a/ değişmesi.

\section{2. /ö/ > /i/}

ölürteçik 'öldürecektir' (T11) < öl-ür-teçi+ök < ölür- 'öldürmek' < öl- 'ölmek' ür [ettirgenlik eki] -teçik [-teçi gelecek zaman eki ve ök pekiştirme edatının birleşmesi ile oluşmuş].

\section{3. $-\mathrm{u} \#>-1 \#$}

matı 'sadık' (BG K14) (Tekin 2003: 250) < Mo. batu (Ölmez 1999: 65), ogll 'oğul, evlat' < ogul (Tekin 2003: 250).

\section{4. $-\mathrm{u} \#+>/ \mathrm{i} /$}

Likän 'kişi adı' (KT K12) < Çin. Lu xiang (Ölmez 1999: 62).

\section{II. Ünsüzlerde Ses Olayları}

\section{8. Ünsüz Korunmas1}

Orhun yazıtlarında ünsüzler söz içinde ve sonunda bulunabiliyorken; söz başında yalnızca belirli ünsüzler bulunabilmektedir. 'baş, çabış 'çavuş', kişi, sıgıt 'ağıt', taş ve yagız 'kahverengi' örneklerinde görüldüğü üzere /b/, /ç/, /k/,/s/, /t/, /y/ sesleri söz başında kullanılabilmektedir. Bu ünsüzlerin dışında kalan /d/,/g/, /g/, /l/, /m/, /n/, /y/, /ńn/, /p/, /r/, /ş/, /z/ ünsüzleri, birkaç istisna dışında söz başında bulunmamaktadır. Köktürkçede /d/, /g/, /g/, /y/, /ń/, /r/, /z/ ünsüzleriyle başlayan sözcük yoktur. Örneğin söz başında \#m/m- ünsüzü kaynak bir dilden gelir: mag 'övgü' ve matı 'sadık' Moğolcadan alınmadır (Tekin 2003: 65). Men zamirindeki ise $/ \mathrm{b} />/ \mathrm{m} /$ ünsüz değişmesidir. Yine alınma sözcükler, şad 'unvan' < İranca, şantuy 'yer (ova) adı' < Çince (Tekin 2003: 66). Ne soru zamiri Toharcada ilgi zamirinden alınmıştır (Ş. Tekin 2001: 254). lagzın 'domuz' (BK G10) < Çince lung (Tekin 2003: 66), şadapıt 'bir unvan' < *şat+pati/apıt 'komutana bağlı garnizon komutanları' (Gömeç 2006: 13). 


\section{$J(\Theta)$}

18.1.

Söz başında, içinde ve sonunda \#b-, /b/, -b\#, \#ø- daha sonra /\#b/ > /\#v/ ünsüz değişmesine uğrayacak ünsüzünün /b/ ünsüzünün korunması: barur 'varır' (KT K 1, BK D 29), täbi 'deve', äb 'ev' (Tekin 2003: 17), bir- 'vermek' (BK D3), sab ‘söz' (BK D1), sebin- 'sevinmek' (BK D2). bol- 'mevcut olmak, ortaya çıkmak, görünmek, yaratılmak' (KT G1).

\subsection{Söz İçinde /1/ Ünsüzünün Korunmas1}

oltur- 'turmak' (BK D2), kelür- 'getirmek’ b(é)d(i)zçi k(e)lürt(ü)m ‘Süsleyici getirdim' (KT G11) (Demirci 2010: 244).

\section{3.}

Damak (ön damak nazal 'genizsil' /y/ ve ince /n\#/ </ń\#/ (/ny\#/) > /y\#/ palatal 'damak') ünsüzünün bulunması: / $\tilde{n} \sim$ ń/ ünsüzünün söz içinde ve sonunda korunması: çıgan < çıgań 'yoksul' > çıgay (Kononov 1980: 33), az+kıńa 'azıcık, pek az' (KT D34, T9), (Ata 2011: 88, 90), ay kanyu 'hani', kanı 'hani', kay 'hangi' <v*kā (Rezaei 2018: 276 277; Clauson 1972: 632). Arkaik diyalekt (eskicil ağız) özelliğidir: Turfan diyalekti ayıg, Orhon diyalekti anıg, Eski Uygurca ańıg (Kononov 1980:34). Söz sonunda da korunmaktadır: yañ- 'yaymak, dağıtmak' (Tekin 2003: 68). Ayrıca bk. ses ayrışması.

\subsection{Nazal /y/ Ünsüzünün Korunması}

Yayılsa 'yanılsa' (BK4), tegri 'tanrı' (BK D1), Kök. yay - 'yaymak, bozguna uğratmak' y(a)ya (é)ltdi 'bozguna uğrattı' (KT D23) (Demirci 2010: 104). Ünsüz değişmesinde /g/ > /y/ başlığı altında örnek verildi. 


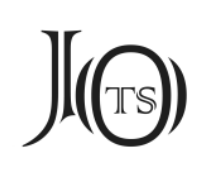

18.5.

Söz içinde, söz sonunda $/ g /{ }^{30}$ ve ek başında ünsüzünün korunması: kagan ‘kağan' (BK D2), azıg 'azı dişi' (IB 6) (Tekin 2003: 239), begler 'beyler' (BK D2), ög‘övmek' (BK G15), kurugsak 'kursak' (IB 8), urg(i)li1 'mutlaka koy' (T34).

\section{6. $/ d /{ }^{32}$ Ünsüzünün Korunmas1}

Eski Türkçe sözcüklerin kök hecesinin sonunda bulunan bir /d/ sesi (=d/)'nin varlığı adag 'ayak' (Tekin 2000: 88) örneğinde olduğu gibi bilinmektedir. Altay dillerinde korunmuş olan AT /*ס/ fonemi sızıcılaşmamıştır. Halaç Türkçesi ve Tuva Türkçesinde korunan bu fonem ancak Karahanlı döneminde sızıcılaşmıştır. Orhon Türkçesinde sızıcı bir fonem olsaydı AT * / > ET d/ > Tuv. - Halç. d/ olamazdı. Sızıcı bir fonemin patlayıcı olması zor iken tersinin olması kolaydır (Ceylan 1992: 110). Sözcüklerin kök hece sonu ünlüleri (=V\#) ile ünsüzleri (=K\#), sonuna geldikleri sözcükleri işlev/anlam karşıtlı̆̆ oluşturarak birbirlerinden ayıran bağımsız fonemleri (ve tabii morfemleri) oluşturmaları durumunda (ko:kol-, te- :tel-...gibi), d/ ünsüzü, aynı sözcüklerin ünlü ile sonlanan (V\#) diğer şekline herhangi bir işlev/anlam farkı oluşturmadan eklenmektedir: ko- : kod-...gibi.

30 odġar- (Orta Türkçe) vb. > oyar- (Ölmez 1988: 45). Orhun Türkçesinde birden fazla heceli kelimelerin sonunda bulunan /g\#/ ünsüzü korunur: älig 'elli', katıg 'katı' (IB 65), kullug 'kullu', ölüg 'ölü', sarıg 'sarı' (IB 11), yadag 'yaya' (Tekin 2003: 243-247). Orhun Türkçesinde ikinci ve daha sonraki hecelerin başında bulunan /\#g/ ünsüzü korunur. Bu durum bugün Özbekçede ve Yeni Uygurca olmak üzere pek çok Türk lehçesinde Orhun Türkçesinde olduğu gibi devam etmektedir. Türkiye Türkçesinde /g/ ünsüzü bu pozisyonda da düşmüştür: kazgan- (> kazan), kergeksiz (> gereksiz), edgü (> iyi), il-

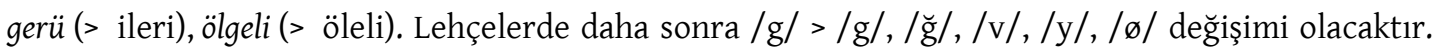
Türkiye Türkçesinde /g/ damak sesinin korunduğu örneklerde anlatımca farklılık meydana gelmiştir. Örneğin, alıngan sözcüğünde 'alışkanlık', sürüngen, dövüşken sözcüğünde 'berkitme' anlamı vurgulanır. Hâlbuki Orhun Türkçesinde \{-gAn\} kılıcı anlamlı sıfat-fiiller yapardı. Krş. esne-gen bars men 'esneyen parsım' (Irk Bitig 10).

Diğer yandan, Eski Türkçenin \{-gAn\} sıfat-fiil eki, dilimizde /g/ damak sesini düşürerek Eski Türkçe ile aynı anlamda \{-An\} sıfat-fiillerini üretmeye devam eder. Krş. esne-y-en parsım.

31 Her ne kadar kıl-fiilinden lehçelerde fonolojik eğilimlerle varyantlarının da oluştuğu emir fonksiyonunda \{+gIl\} ekinin geldiğini düşünenler olsa da -ki kabul görmediğinden- bu ekin Türk dilinin muhafazakârlık özelliğine dayanan bir pekiştirme eki olduğu saptanmış ve eskiden beri var olan bir ek olduğu belirtilmiştir (Caferoğlu 1971:3, 9). Yani /k/ > /g/ ünsüz değişmesi olmamıştır.

32 Daha sonra /d/ > /y/ ünsüz değişmesi olacaktır: odġar- > oyar- (Ölmez 1988: 45). 


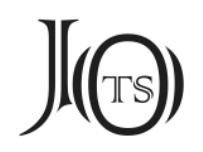

Bu durum, diğer iki önemli morfofonetik sürecin bir sonucu hâlinde tezahür etmiş olmalıdır: Biri, tek heceli sözcüklerin /d/'leri ile, aynı sözcüklerin ünlü (V) ile sonlanan şekillerinin kök ünlüsünün $(\mathrm{V} /)$ uzunluğu arasında morfofonetik ni-

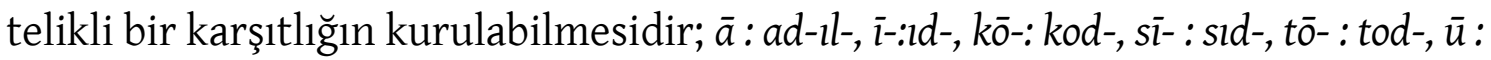
ud gibi. Diğeri ise, /d/'nin, benzerine rastlanılmayan bir şekilde, ekte değil de sözcükte ortaya çıan bir 'destek ünsüzü’ niteliğidir. Eklerin eklenme sürecinde ortaya çıkan 'gedik dolduran türemesi aşaması'dır: $\bar{a}^{*}-$ a adıl-, $\bar{\imath}-:$ : d-ış-, kō-: : kōd-ul-, ö- : öd-ür-, sī-: sld-lg, sī- : sid-ik, u : ud+l-ku, yā- : yad-ıl- gibi (Turan 2012: 69). Ancak sözcüklerin uzun ömür sürecinde oluşan fonetik hadiseler nedeniyle, kök vokalinin anlam ayırt ediciliğinin, oluşan çoklu sesteş sözcüklerin köklerinde büsbütün bulanması sebebiyle, /V+uzunluk/ : d/ karşıtlı̆̆ının, bu sözcüklerin hepsinde birden işletilemediği de tespit edilmiştir: kō- :kod-, tō- :tod- ... örneklerinde sorunsuz kurulan karşıtlık, ke/i*-: ke/id- 'giymek' sözcüğüne benzer biçimde olan ki- 'girmek' fiili için, morfofonetik karşılığı olması beklenen sesteş kid- şekli ile oluşturulmamıştır. Öyle olduğu düşünüldüğü için eklerin de her zaman, /d/'li karşıllı̆ı kullanılamayan bu ki- şeklinin sonuna eklendiği görülmüştür: ki-r, kigür- ... (Turan 2012: 77).

\subsection{Ekte /k/ Ünsüzünün Korunması}

Ek başında /k/ ünsüzünün korunması: isirke- 'bir kayıp için üzülmek' (Tekin 2000: 88).

Söz içinde ekleşme sırasında /-k-/ ünsüzünün korunması: ki-k-(i)ş-ür- 'kışkırtmak' (KT D6) (Sertkaya 2011: 239).

\section{9. Ünsüz Düşmesi}

\section{1. $+\mathrm{g} \#>/ \varnothing /$}

Söz sonunda veya ekin sonunda / $g \# /$ ünsüzünün düşmesidir; yarlika- 'buyurmak, esirgemek, lütfetmek' < yarlıg+ka- (Clauson 1972: 968a) Kök. yarlıka- 'buyurmak, esirgemek, lütfetmek', t(e)yri y(a)rl(i)k(a)dukın üçün 'Tanrı lütfettiği için’ (KT G9) (Demirci 2010: 166), kunçuy 'prenses' < Çin. kung çu 'imparatorun kız1' (Tekin 2003: 249), gong zhu (Ölmez 1999: 59). 


\section{$J(\Theta)$}

\section{2.*\#h- > \#Ø-}

Söz başında uzun kök ünlüsü kısalırken /h/ ünsüzü düşer: a a 'az, birkaç, çok değil' (KT G10) < İT *hāŕ, adak 'ayak' (KT K7) < *hadak, açıg 'acı' (Ozn. I) (Tekin 2003: 237) < *haç1- (Choi 2019: 81), ardıl- 'ayrılmak' (T12) < *hadır- (Choi 2019: 82) $\mathrm{vb}$.

\section{3. $\mathrm{n} \#>\varnothing \#$}

Künüy 'Iramak adı' (Tar. B5) < Mo. Huniyn (Tekin 2003: 249).

\section{4. /ng/ > Ø\#}

ançola- 'sunmak, takdim etmek' (KT D32) < Çin. an chang + Tü. \{+lA-\} (Ölmez 1995: 228).

\section{5. *\#p- > \#f- > \#h- > Ø-}

Halaç Türkçesinde /\#h/ (hadaq 'ayak' <*padakur²) olan Ana Altaycada /*p/ biçiminde canlandırılan ses daha sonra süreklileștikten sonra Türk dilinde *p>> Ø şeklinde gösterilmektedir (Tuna 1983: 30).

\section{6. $+/ \mathrm{r} / \sim+/ \mathrm{k} />\varnothing \#$}

Yine ekleşme sırasında görülür. Ancak bu ünsüzün $/ \mathrm{r} / \mathrm{mi} / \mathrm{k} / \mathrm{mi}$ olduğu tartışılabilir: üze 'yukarı, yukarıda' (BK D2) [ * *üz 'üst, yukarı' +re [yön gösterme eki] < *üzgere (Kononov 1980: 79)], asra 'aşağ1, aşağıda' (BK D2) (<* as 'aşağı' +ra [yön gösterme eki]). Altay dillerinde asıl yönelme hâli eki $\{+k A\}$ dır ve $\{+A\}$ şekli ünsüz düşmesiyle oluşmuş ve iyelik ekli sözcüklerde yaygınlaşmış diye düşünülmektedir (Eraslan 2000: 72). Yakın benzeşmeyle ünsüz değişmesinden sonra ( $q g$ > qq > q) ekleşme sırasında ünsüz düşerek tekleşir; balıqa (T 18) 'şehre' < balıqqa < *balıqga (Kononov 1980: 71). Dikkat çeken bir örnek ise yön gösterme ekini alan ayar zamiridir. ${ }^{33}$ Ayrıca adaq 'ayak' < *adakur (Tuna 1990: 266).

33 Ünsüz düşmesi (phonological erosion) yönelme ve yön gösterme eki aldığında önce sonu /n/ zamiriyle biten kelimelerde $\{+(\mathrm{GA}) \mathrm{rX}\}$ yön ekinde çevre şartına uygun olarak /g/ ünsüzünün erimesiyle başlayıp /y/ ile sonuçlanır; baya / mana, bayaru, saja / (yok), ajar / ajaru. Fonolojik eksilmeyle başlangıçta ekin sonundaki / $\mathrm{u}$ / ünlüsü düşmüş, iki aşamalı olarak / $\mathrm{r}$ / ünsüzü ile sonuçlanmış sonra /r/ ünsüzü de düşmüştür sonuçta yönelme şekline sinonim olarak yaklaşmıştır. Orhon Türkçesinde yön gösterme eki işlek olmadığını için fosilleşme kanıtını sergilemiştir (Maki 2017: 5). Burada yönelme eki 


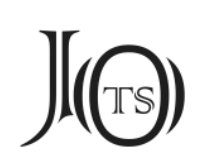

\section{7. $/ \mathrm{n} \# />\varnothing \#$}

Moğolca çokluk eki $\{+\mathrm{d}\}$ ile karşılaştırılmaması gereken $\{+(\mathrm{X}) \mathrm{t}\}$ çokluk eki geldiğinde /n\#/ ile sonlanan adlar üzerine eklendiğinde /n/ sesi düşer: tigit (Tar. K2) 'prensler' < tigin, tarkat (KT G1) 'tarkanlar' < tarkan (Ata 2017b: Ünite 3). Söz öbeğinde geçen ekin 'iki' (BK G1) < *ēkin, yagin 'düşman, savaş' (MÇ K6) < *dagin sözcüklerindeki /n\#/ ünsüzü düşerek eki (KT D1), yagı (KT K8) olur (Tekin 2003: 78).

\section{0. Ünsüz Türemesi}

Yukarıda birincil uzun ünlüler işlenirken irdelendi. Burada tekrarlandı.

\section{1. \#y- Türemesi}

\subsection{1.}

Söz başında /-y, \#y/ ünsüzünün türemesi: $\imath d-<{ }^{*}$ 1-d- 'göndermek' Kök. 1d-, yıd- 'göndermek, terk etmek' $(a) r k(1)$ ştirk $(i){ }_{S ̧} \imath(d) s(a) r$ 'kervanlar gönderse' (KT G8) ança yıdmış 'böyle göndermiş' (T K10) (Demirci 2010: 219). Yukarıda birincil uzun ünlünün neden olduğu bir ses olayı olarak gösterildi.

\subsection{2.}

Söz sonunda y\# türemesi: kunçuy 'prenses' < Çin. kung çu 'imparatorun kızı' (Tekin 2003: 249).

\section{2. $\bar{v} d /$ Ünsüzünün Türemesi}

Ünsüz korunması maddesinde işlendi, bk. ko-d-.

\section{3.}

Ünlü ile biten sözcükten sonra ünlü ile başlayan ek başında bağlantı sesi (bağlama ünsüzü) /y-, y\#/'nin geçici olarak iki ünlü arasında kayan ses olarak türemesi: öyür ermiş 'düşünür imiş’ (KT G5) < ö- ‘düşünmek' -(y)ür er-miş [3. teklik kişi geniş zamanın rivayeti], yorıyur 'yürür ' (KT G9) < yort-' yürümek' -(y)ur [2. teklik kişi geniş zamanın eki].

işleklik kazanırken fonksiyon yakınlığı bakımından sinonimi olan yön gösterme ekinde *an\#+karu > ay+garu > ayaru > ayar [> aya > ana 'ona'] şeklinde gelişen bir morfo-fonolojik oluşum düşünülebilir. 


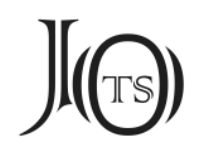

\section{4. +n\# Ünsüz Türemesi}

Ek genişlemesinde $\{+(X) n\}$ morfemi ile genişeleme görülmektedir; karıg söküpen 'karı söküp' (BK D27) (Sevinçli ve Çiçek 2019: 1260).

\section{1. Ünsüz Tekleşmesi}

+kk > /k/: Ekleşme sırasında sözcüğün sonundaki ünsüz ile ekin başındaki ünsüz aynı olduğunda görülür: ulug 'ulu (kişi), önder' (T B5) < ullug < ul ‘temel, esas' +lug [isimden isim-sıfat yapım eki: ünsüz tekleşmesi ile ulug] +1 [3. tekil kişi iyelik eki], 1 - 'göndermek' -duk < 1-d- [-d- fiilden fiil yapım eki] -duk [sıfat-fiil eki: ıduk ${ }^{34}$ yiri subl 'kutsal yeri suyu (vatanı)'] (KT D10), balıqa (T18) 'şehre' < balıqqa < *bahıgga, yaratıdım 'yarattım' < *yaratıddım < yaratıtdım, yögärü < yöggärü < yökgärü, igitim 'besledim' < igittim <*igitdim, qorqınçıg 'korkunç' < * qorqınçsıg < * qorqınç 'korku'+sıg (Kononov 1980: 71).

\section{Erime}

/VgV/: nälök 'niçin' (IB 57) (Tekin 2003: 250) < *ne+gü ol+ök [\{+gUl\} < $\{+g U\}+o l]$ (Erdal 2004: 125) [ne soru sözcügüü üzerine Orhon Türkçesine mahsus gU soru edat1] $]^{35}$ veya < ne+(A)gU+1Xk (Erdal 2004: 60 213), [ilk ünlüyü takip eden iki ünlü arasındaki /VgV/ ünsüzü açıklığının etkisiyle niteliği silinerek ilk ünlü içinde kaybolur], ayrıca bk. ünlü çatışması ve hece düşmesi.

\section{3. Ünsüz Nöbetleşmesi}

\subsection{Sözcükte Ünsüz Nöbetleşmesi}

\subsection{1. /ç/ /z/}

bar-zun, bol-çun [3. teklik kişi emir eki -çun>-zun>-sun>-sIn].

${ }^{34}$ Issık Köl 'kutsal göl' adında da aynı kökten gelir: $ı s s ı k<*{ }_{1} t_{1} 1 k<* 1 t t ı k<* 1 d-d u k<*{ }^{*}$ hi:-d-di+ök [Krş. Halç. hị:dlk 'kutsal' (Doerfer-Tezcan 1980: 130)]. Türklerin dini inançları ile ilgili irdelemelerde dağın ıduk yani kutsal olduğu saptanmıştır. RADLOFF, Sibirya'ya yaptığı gezide Altay Türkleri ile ilgili olan bir göl kenarından geçerken Altın Tag (Dağ)'tan uğur istediklerini tespit etmiştir. Altay Türkleri Altın Tag'1 gök ve dağların atası olarak kabul etmektedirler. (2006: 96).

35 mU, Orhon Türkçesi metini T yazıtında iki kez saptanmıştır (Çetin 2008: 311). 


\section{$J(\Theta)$}

\subsection{2. $/ \mathrm{y} / \sim / \mathrm{g} /$}

Genizsil damak ünsüzü /y/ötümlü art ve ön damak sızıcıları /y/ve /g/ ile

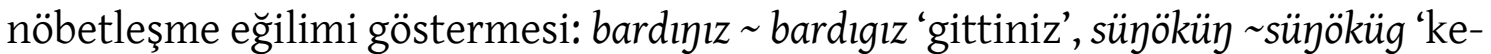
miklerin', bar-d(1)g 'gittin' (BK D20), içik-d(i)y ‘bağımlı oldun' (KTD 31) vb. (Tekin 2003: 17, 55), öltüg ‘öleceksin' (KT G6) < öl- 'ölmek’ +tüg [2. teklik kişi belirli geçmiş zaman eki $\eta \sim g$ nöbetleşmesiye], yine benzer şekilde ölsikig 'öleceksin' (KT G6) < öl- 'ölmek' +sikig [2. teklik kişi gelecek zaman eki /y/ /g/ nöbetleşmesiyle], alkın- 'tükenmek' (KT G9) < alk- 'tükenmek, mahvolmak' -(ı)n [fiilden fiil yapım eki, dönüşlülük eki] -tıg [2. teklik kişi belirli geçmiş zaman eki, /y/ /g/ nöbetleşmesi ile], yorıyur ertig 'yürür idin' (KT G9) < yort- 'yürümek' -(y)ur ertig [2. teklik kişi geniş zamanın hikâyesi eki, $/ \mathrm{y} / \sim / \mathrm{g} /$ nöbetleşmesi ile], türük bodun il+ig+in törü+g+in kem artatı udaçı erti (BK D19) ‘Türk halkı (senin) devletini ve yasalarını kim bozabilir idi' [belirtme durumu (yükleme, akuzatif) $\{+(\mathrm{X}) \mathrm{g},+(\mathrm{I}) \mathrm{n}$, $+n I\}$ eklerinden biri olan $\{+(\mathrm{I}) \mathrm{n}\}$ eki geldiğinde ikinci tekil kişi iyelik ekinden $\{+i \eta$ $+g+\}$ sonra gelmesi ve törü $+g+$ in yapısında $/ \mathrm{y} / \sim / g /$ nöbetleşmesi ile $+g$ ikinci teklik kişi iyelik ekinin gelmesi] (Ata 2017b: Ünite 3).

\subsection{3. $\mathrm{m} \sim \mathrm{b}$ Nöbetleşmesi}

tarbanka 'Tarman'a' (BK D18) tarmanka < Çin. t'anman (dağları) (Tekin 2003: 71).

\subsection{4. /t/ /d/ Nöbetleşmesi}

yagıt- yagıd- 'düşman olmak' < yagı ' savaş, düşman', yagıt < $d$ >okda 'düşman olduğunsa' (KÇ D6) (Soydan 2017: 875), (KÇ 18) (Tekin 2003: 257).

\subsection{5. /1/ /ş/ Nöbetleşmesi}

Bk. ş< l $>\mathrm{r}^{2}>\mathrm{z}, \mathrm{l}>$ ş alt maddesi kll-ve kış- 'etmek, yapmak' (KT D32). ${ }^{36}$

\subsection{6. *\#g > \# \#y}

ET $\imath d-$, tt-, id-, yld- (Tekin 2003: 244) < IT *\#gid 'Alm. entfernen, uzaklaştırmak' (Tuna 1990: 260) ve devaminda 14 örnek daha var.

36 Bk. oguş < ogul > ogur > oguz > uz, kök(ï)r(ek) 'göğüs' < Çă̆. kökül+taş 'sütkardeş', Mo. kökel 'süt verici' $>$ kögüz 'göğüs' (Ünlü 2013: 654). 


\section{J(৫)}

23.2.

Ekleşmede ünsüzlerin sıfırla nöbetleşmesi: Türkçenin tek yardımcı ünsüzü /y/'dir. (Demir-Yılmaz 2014: 158 ). /y/ / /: kurya kurıya 'geride, batıda' < kurı 'batı' (Tekin 2003: 68), ulayu 'önce' < ula- 'bağlamak' (Tekin 2003: 256).

\section{4. Ünsüz Kaynaşması}

süçig 'tatlı' (KT G5) < süt 'süt' + sig 'süt gibi olmak' [isimden isim, sıfatyapım eki. Sözcük kökünün son sesi /t/ ile ek başı/s/ seslerinin kaynaşmasından dolayı hece başı ünsüzü /ç/'dir] (Ata 2011: 149), (Erdal 2004: 70), /tç/ > /ç/: oçok 'ocak' [<*ot+çok (Erdal 2004: 113), ${ }^{37}$ [ōç+ak 'evde ateş yakılan yer' < Orh. ōt 'ateş', ortu 'orta' +s1 [3. teklik kişi iyelik eki] +n [araya zamir /n/'sinin girmesiyle kaynaşma] +yaru [yön gösterme ekinin ilk sesi /g/ ile zamir /n/'sinin kaynaşması sonucu yön gösterme ekinin ilk sesi /y/'ye dönüşmesiyle kaynaşma] > ortosin(a)ru 'ortasına, ortasına doğru' (KT G2) < *orto+sin+garu (Tekin 2003: 77), tunukuk 'Tunyukuk' (genel olarak) < tuńukuk (BK G14) < tun 'ilk' + yukuk 'vezir' [iki sözcüğün birleşmesinden sonra /ny/ > /ń/ şeklinde söz içinde ikin ünsüzün birleşip tek ünsüz hâline gelmesi] (Tekin 2003: 77).

\section{Eğilti/Sı̆̆ınım (Enkliz)}

Vurgusuz bir sözcüğün kendinden önceki daha vurgulu kelimeye dayanması, sona sığınma (İpek 2016: 15-35; Güven 2016: 265). İki kök sözcüğün birleşmesinde anlamca baskın olan sözcük - bazen ses uyumu sıralamasına aykırı olarak sonra gelen önce gelene uymadan - diğerini kendisine benzetir; yalyusin [yorlyur 'yalnız başına yürür'] (IB) < yalıus / yalınus < yalıng+öz 'yalnız' (Tekin 2003: 258).

\section{6. Ünsüz Uyumuna Uymama/Benzeşmeme}

Köktürk işaretleriyle yazılan Orhon anitlarında ünsüz uyumu bulunmamaktadır (Gülsevin 1990: 59). Ötümsüz /ş/ ünsüzünden sonra ekleşme sırasında ötümsüz /t/ yerine ötümlü /d/ ünsüzünün gelmesi sün(ü)şd(ü)m(ü) z 'savaştık' BK D28 örneğinde görülmektedir. Tam tersi de olabilir. Ötümlü /r/ titrek-akıcı ünsüzünden sonra ötümlü /d/ yerine ötümsüz / $t$ / ünsüzünün gelmesi birt(i)m(i)z

37 DLT köçök 'kalça' < köt+çök (Erdal 2004: 113). 


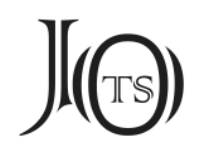

'verdik' (KT D20) örneğinde görülmektedir. uçdı ‘uçtu' (KT KD), ölti 'öldü’ (KT D33) vb.

Gelecek zaman kipinin \{-DAçI\} eki: olor-taçı sän 'yaşayacaksın', öl-täçi sän 'öleceksin', vb. (Tekin 2003:18) ile yine gelecek zaman kipinin \{-çI\} eki ötümlülük uyumuna girmemez: tägmä-çi män ‘hücum etmeyeceğim' (0 sağ 2), yarama-çı ‘yaramayacak, iyi olmayacak' (T 23), vb. (Tekin 2003: 18).

Aidiyet eki \{+GI\}: bod(u)nkı 'düşman halkınınki' (Tar. B5) (Tekin 2003: 56), tabgaçgl (< tabgaç 'Çin' +gl [aidiyet eki]) (BK D7) örneklerindeki gibi ötümlülük ve ötümsüzlük uyumuna tabi olmamıştır.

Daha çok örnek verilebilir ancak çalışmanın hacmini genişletmemek için birer örnekle yetinildi. Sözcükte görülen aykırılaşma yukarıda işlendi. Benzeşmeme ekleşmede görülmektedir.

\section{Biçimlik Yapıda Seslik Özellik}

Ekleşme sırasında ekin asli sesinin tezahür etmesidir. İlgi durumu $\{+(\mathrm{n}) \mathrm{In}\}$ ekinin ünsüzlerden sonra $\{+I \eta\}$, ünlülerden sonra $\{+n l y\}$ ile kurulmasi: bilge ka-

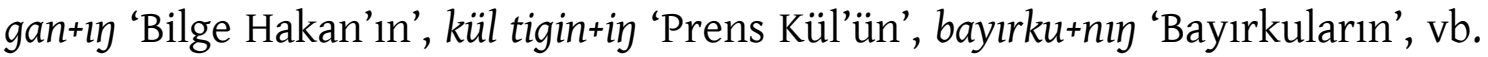
(Tekin 2003: 17). İlgi ekinde konuya değinildi. ekin ara 'ikisinin arasında' (KT D1, antag 'onun gibi' (KT D4), alpın üçün 'alplığının ucuyla (sebebiyle)' (TII G4) vb. (Özdemir 2019: 156 157). Burada asli sesin zamir /n/'si olduğu görülür.

\section{Benzer Hecenin Düşmesi}

$/(\mathrm{u}) r />/ \varnothing /:$ yug(u)rga '(kan) yoğururcasına' (T26) < *yugur-ur-ga örneğinde benzer seslem yitimi olmuştur (Tekin 2003: 63). Burada dil kakafoniden kaçınmıştır. Yukarıda ünlüler başlı̆̆ı altındaki hece düşmesinde orta hecedeki dar ünlüler düşmekteydi. Burada ise titrek $/ \mathrm{r} /$ ünsüzsüne sahip $\{-(u) r g a\}$ zarf-fiil ekindeki /ur/ hecesi veya yugur- sözcügünün sonundaki /ur/ hecesi benzerlikten dolayı düşmektedir. Bunun için ünlüler kısminda değil ünsüzler başlığı altında gösterildi. Ünlüler başlığı altında da (orta) hece düşmesinden söz edildi.

\section{Yer Değiştirme (Göçüşme)}

balbar 'öldürülen düşman heykeli' (Tuva III3) < *barbal < *barmal < Mo. barimal 'heykel', arkış 'alkış' (Tuva 14) < *alkış (Tekin 2003: 77), qoşnı 'komşu' (DTC 


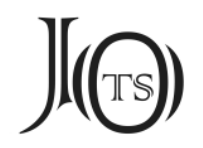

455) < qonş1, badga- 'bağdaş kurmak' < bagda-, yamgur 'yağmur' < yagmur (Kononov 1980: 72, 73).

\section{Eşgösterenlilik ${ }^{38}$}

Ses değişmesinden 'sound change' (*-g\# > - $\eta \#,-n \#$ ünsüz değişmesinden) kaynaklanan eşgösterenliktir (Atmaca 2013: 126): kalın 'kalın; kalabalık', kalı 'başlık parası' ${ }^{39}$ (Suçi 7) (Tekin 2003: 245), kalı 'kalabalık, çok sürü; kalın, kesif' < *kalag (Tuna 1990: 270) < kal- 'kalmak; umutsuz durumda olmak' (Tekin 2003: 245) < ka- 'eklemek, koymak'. Kalancı 'tarlada vergi için bırakılanı toplayan kişi' terimindeki kalan 'tarlada kalan ürün; devletin toprak vergisi (Atmaca 2013: 127)' sözcügünün başlık parası anlamındaki kalın kavramı ile benzerliğine dikkat çekilmiş ve etimolojik açıdan uyumlu olduğuna vurgu yapılmıştır (Karakurt 2017: 222).

38 'Türk dilinin kelimelerine genel yapı itibarıyla bakıldığında araştırmacılar tarafından eşadlılık, eşseslilik [ homophone omofon (<Eski Grekçe homos 'benzer' +phone 'ses')] ve eşyazımlllık [ homograph omo-graf (<Eski Grekçe homos 'benzer' + garpho 'yazı')] başlı̆̆ı altında verilen örneklerin birbirine karıştırıldığı görülür. - Eşseslilik, 'kimi dillerde görülen yazılışı ayrı, söylenişi aynı olan sözcüklerin; eşadlılık, 'gösterileni ayrı, göstereni özdeş olan sözcüklerin; eşyazımlılık 'kimi dillerde görülen, söylenişi ayrı, yazılışı aynı olan göstergelerin' özelliğidir. - Bu sebepten bu terimler arasındaki karmaşaya son verecek ve her üç terimi de üst kategoride kapsayacak 'eşgösterenlilik' terimi kullanılmalıdır. Eşgösterenlilik, genellikle tek veya iki heceli kelimeler arasında gerçekleşen, dilde ses değerleri bakımından aynı; fakat anlamları ve fonksiyonları bakımından farklı olan kelimelere denir.' (Atmaca 2013: 117).

39 'Bütün Türk lehçelerinde kalın 'başlık parası'; kal- fiil köküne, fiilden isim yapan eklerden /-n+/ getirilerek yapılmış (kalı-n) bir kelimedir’' (Turan 1991: 39). 


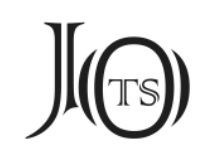

\section{1. Ünsüz değişmesi}

\section{1. l'leşme ve r'leşme $\mathrm{z}<\mathrm{r}<1>\varsigma^{40}$}

‘Genel Türkçe /z/, /ş/'nin Çuvaşçada /r/ ve /l/'ye denk geldiği bilinmektedir. Altayistik kuramında $\mathrm{r}>\mathrm{z}$ ve $\mathrm{l}>$ ş gelişmelerine 'Zetasizm' ( $\mathrm{z}$ 'leşme) ve ‘Sigmatizm' (ş'leşme); bunun tersine, /z/ > / $/$ ve /ş/ > /l/ gelişmelerine ise 'Rotasizm' (r'leşme) ve 'Lamdasizm' (l'leşme) adı verilmektedir.' (Eker 2004: 230).

\subsection{1. $/ \mathrm{r} />/ \mathrm{z} /$}

r\# > z\# yabız < *yabır 'fena, kötü' (Tekin 2003: 87), āz 'az, birkaç, çok değil' (KT G10) < İT *hāŕ. /r/ /1/ değişimi /r/>/l/ yönünde olmakla birlikte Türkçede bunun aksini gösteren örneklerle de karşılaşılmaktadır. /l/>/r/ ünsüz değişimi daha eskicil (arkaik) olabilir. Kür sözcüğü ise hem 'hile' hem de 'cesur' anlamındadır. Köl Bilge Han eski bir unvandı (Nalbant 2018: 162). Eski Batı Türkçesi LIR ve Eski Doğu Türkçesi ŞAZ meselesinde ş < l > $\mathrm{r}^{2}>\mathrm{z}$ (uguş < *ok 'boy örgütü' ${ }^{41}+\mathrm{ul}>$ ogur > oguz) şeklinde bir ses değişimi görüldüğü bilinmektedir. Çağataycada kökel+taş 'süt kardeşi', buradan kök+ür > kök+üz > göğüs şeklinde bir gelişme düşünülebilir (Hazar 2003: 131), (Poppe 2008: 104).

\subsection{2. $1>$ \$̧}

bişük 'akraba' (KT G6) < *büşük [<*bül < *pöl] >> MKo. p'ar (Choi 2019: 96; Tekin 1979: 149, yok kış- 'yok kılmak', baz kıl- 'bağımlı kılmak' (KT D2). Bir eskicil duruma örnek olan /l/ : /ş/ ses denkliği var. Altay dillerinin akraba olduğu görüşünün ilk delillerinden biri olan $/ 1 /$ : /ş ${ }^{42}$ denkliğinin örneği kıl-/kış- fiilinde

40 Yukarıda l ş nöbetleşmesinde geçmişti. Moğ. kökel ‘süt verici' (Ünlü 2013: 654) [köküş < kökül > kökür > köküz > köküs 'göğüs', <*kö-k 'yukarıya kalkıp yuvarlaklaşan' <*kö- 'yükselmek', [/1/ dualite bildirir. Muhtemelen el 'iki el' sözcüğünün ikincil kelime olup ekleşmesinden gelmektedir.] ve ogul [oğuş < ogul > ogur > oguz > uz] örneklerinde izosemantizm yani anlamsal gelişimin paralelliği kuralına uyum bariz olarak görülmektedir. \{izo+\} 'benzerlik' anlamı için bk. (Lampropoulou 2017: 341). /ş/'nin zayıflayıp /1^’leştiği de düşünülmektedir (Barutçu 2002: 204).

${ }^{41}$ Oksuz 'örgütsüz, bağımsız’ BK D4.

${ }_{42}$ Altay dilleri teorisine bir delil de /r/ : / z/ denkliğidir (Ramstedt 1957: 49, 64). Eski Batı Türkçesinin izleri olan rotasizm 'r'leşme' ve lambdaizm 'l'leşme' (ŞAZ: LíR meselesi) Eski Doğu Türkçesi ile Eski Batı Türkçesinin ayrımına delildir (Tekin 1987: 11). 


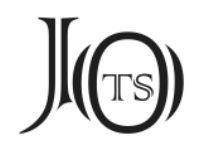

görülür; yok kış- 'yok kılmak' (KT D32), ${ }^{43}$ baz kıl- 'bağımlı kılmak' (KT D15), oguş 'boy' (BK D31) ogul 'evlat' ile benzer; beglik oglugun kul kıldık, işilik kız ogluyun küy kıldık [beylik oğlunu kul kıldık, hanımlık kızını cariye kıldık].

\section{Benzeşme}

İki varyantı da olan balbal ve balbar sözcüğü her ikisine de örnek olur. Ayrıca dar ünlü düşmesinde de işlendi. Ünsüz-ünlü yakın benzeşme de görülebir: töpö 'tepe' < *täpä (Erdal 2004: 95) [bk. yukarıda ä > ö].

\section{1. İlerlek Benzeşme}

\subsection{1. $/ \mathrm{m} />/ \mathrm{b} /$}

balbar 'öldürülen düşman heykeli' (Tuva III3) < *barbal < *barmal < Mo. barimal 'heykel', (Tekin 2003: 77).

\subsection{2. /d/ > /ç/}

küçüg 'iş güç' [işig küçüg birmiş] (BK D8) < küdüg (Erdal 2004: 97) ayrıca bk. ötümsüzleşme.

\subsection{Gerilek Benzeşme}

sök- 'diz çökmek' (KT D35) < çök- (Gürer 1990: 62) < AT *çöү-, /r/ > /l/ balbal ‘öldürülen düşman heykeli' (Tuva III3) < *barbal < *barmal < Mo. barimal 'heykel', (Tekin 2003: 77). Ünlü kalınlaşması ve nazalleşmeden sonra dudak benzeşmesi; *ben+ge > baya (T31) > mana (KT D30) (Ata 2011: 109). ${ }^{45}$ Söz sonundaki $n \#$ ünsüzü-

${ }^{43} / \mathrm{l} /$ : /ş/, kış- 'kılmak, etmek, yapmak' ol süg (a)nta yok kışd(l)m(l)z 'Orduyu orada yok ettik' (KT D32).

44 5. Dip nota bk.

45 'b- ile başlayan sözcüklerde genizsi bir ses olan /n/ ve /y/ var ise söz başındaki $b$ - > m-'ye gelişir. ben men olur. T yazıtı bu sözcüğün asıl şeklini korurken BK ve KT yazıtlarında men şekli kullanılmış. T’ta ben zamiri üzerine nesne durumu ile yönelme durumu ekleri geldiğinde de $b$-'li yapı tercih ediliyor: bini, bana. Fakat b-ile başlayan başka sözcüklerde $b$ - > $m$ - değişikliği söz konusu edildiğinde sadece T yazıtının bu eskicil özelliği koruduğu söylenemez. 'bun, sıkıntı' anlamındaki sözcük, KT G3'te buy şeklinde geçmekte. Aynı sözcüğ̈̈n ek almış şekilleri buysız'dertsiz' BK K14, bunad- 'bunalmak' T 26'dadır. Bu sözcükler, Köktürk harfleriyle yazılmış Irk Bitig'de ise m'li olarak yer almakta. Yine 'binmek', 'bin' ve 'bengü, ebedi' anlamlarındaki sözcükler üç büyük yazıtta da Türkiye Türkçesinde olduğu gibi b-'lidir: beggü KT G8, BK K6; bin- KT D33; bintür- T 25; bin BK G1, T 14. Bu kelimeler 


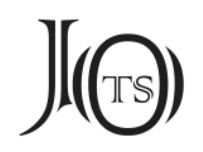

nün gerilek etkisiyle benzeşerek $/ \mathrm{b} />/ \mathrm{m} / / \mathrm{b} /$ dudak ünsüzü yarı burunsallaşmayla /b/ > /m/ değişmesine uğrar. Modern Türkiye Türkçesinde hâlâ korunmakta olan bän 'ben' Köl Tegin yazıtında asimile ikincil formu olan män'a sahiptir (Erdal 2004: 10). Yukarıdaki ünlü uyumuna da giren bir konudur. Yönelme durumunda baya (T32) şeklinde ses değişikliğinin nedeni ünlü uyumundan kaynaklanan zorlayıcı ve gerileyici bir benzeşmedir. Kalın sıradan / $\mathrm{b}^{1} /$ ile yazılmıştır Zamirdeki kök değişimi anlamsal değildir. Burada bir ses değişimi vardır (Eraltay 2019: 45). Gerilek benzeşme başlığında /*m/ > /b/ değişmesi işlendi.

\section{Bulaşma}

\section{1. \#b- > \#m-}

Birinci teklik kişi zamirinin sonundaki diş-dudak geniz ünsüzü /n-/'nin gerileyici benzeşmesi ile - nitekim ikinci teklik kişi zamiri sen'de /-s/ ünsüzü dudak ünsüzü olmadığı için bu gerileyici benzeşme gerçekleşmez - Birinci çokluk şahıs zamiri biz'in miz olması ise ben > men genizleşmesinden 'bulaşma (contamination)' olması düşünülebilir (Sertkaya 2014: 10).

\section{4. Ötümlüleşme}

\subsection{1 \#g- > \#k- Ötümlüleşmesi}

gaşga 'alnı akıtmalı (at)' (E 41/11) (Aydın 2013: 42).

\subsection{2. $/ \mathrm{k} />/ \mathrm{g} /$}

ya-g+u-t- 'yaklaşmaktırmak' [ya- 'yakın olmak, yak 'yakın', ya- $k+u-$ 'yaklaşmak' < *yak- > Orh. yaguk, yakın, yagu-, yak- (Choi 2019: 129)], yagur-u 'yaklaşmak' (KT G5).

başka Türk lehçelerinde m-'lidir (min, min-, vs.).' (Ata 2017b: Ünite 3). Ancak Ana Altayca düşünüldüğünde tersi düşünülmektedir. buñsız 'dertsiz, kaygısız, sıkıntısız' < buñ 'dert, sıkıntı' (Tekin 2003: 83) < munğ 'sıkıntı, 1stırap, mihnet' (Soydan 2017: 880), Ana Altayca düşünüldüğünde $m$ > b değişmesi daha arkaik düşünülmektedir (Tekin 1992: 83). 


\section{$J(\Theta)$}

\subsection{3. $/ \mathrm{k} \# />/ \mathrm{g} \# /$}

ögs(ü)z 'öksüz, anasız; akılsız’ < ök 'akıl, anlayış' [<*ō-/ö:- 'düşünmek'], 'Ög kelime kökü \{+sUz\} ekiyle birleşirken ekin başındaki /s/ ünsüzü dolayısıyla ög kelimesinin sonundaki g\# de k\#'ye dönüşmüştür.' (ilhan 2011: 476).

\section{2. $\mathrm{t}>\mathrm{d}$ ötümlüleşmesi}

\subsubsection{Sözcükte Ötümlüleşme}

Köktürk Türkçesi sözcük sonunda ötümlü /d/ fonemi 'anlam ayırt edici ses' bulunan tek seslemli kimi adlarda birincil uzun ünlünün kaybolurken /t/ ünsüzü /d/ ünsüzüsü olarak ötümlüleşerek değişir. Sözcüğün Ana Türkçede uzun ünlülü olduğunun bir belirtisi de günümüzde birincil uzun ünlülerin varlığını koruduğu iki çağdaş Türk lehçesindeki (Yakut ve Türkmen Türkçesindeki) uzun ünlülü diğer bir deyişle çift ünlü kullanımıdır: öd 'safra kesesi'<*AT öt 'safra kesesi' (Tekin 1975: 268 ) > Yak. üös 'öd, safra kesesi' (yükselen diftong), Trkm. ö:t 'öd, safra kesesi': öd+iñ[e] küni: t(e)gdük üç(ü)n (BK D29-30) (Tekin 2010: 60).

\subsubsection{Ekleşmede Ötümlüleşme}

Tek seslemli eylemlerden $\imath t$ - ld- 'göndermek' sözcügüü de Orhon yazıtlarda ikili kullanımla, ötümlüleşmiş biçimleriyle de kullanılmaktadır: $t$-tı, ıt-tım, $t$-ttmız, ıd-ıp, ıd-maz, ıd-mış (KT G12, BK D40, KT D40, BK D35, BK D25, KT D6). Çok seslemli eylemlerde ise bir sözcükte «geçici» ötümlüleşme vardır: igid-/igit- 'beslemek, doyurmak': igid-eyin, igid-ì, igid-miş, igid-ür, igit-ti, igit-tim (KT D28, BK K13, KT G9, KT GD, KT D16, KT D29) (İnce 2019: 136), katıgdı'sağlamca' (KT G2) < kat- 'katmak, katılaştırmak' -(l)g 'katı' [fiilden isim yapım eki] +tı [isimden isim -zarf- yapim eki].

\section{3. /ç/ > /c/ Ötümlüleşmesi}

uçuz > ucuz (Ata 2011: 89).

\section{5. Ötümsüzleșme}

\subsection{Ekleşmede Ötümsüzleşme /nd/ > /nt/}

bodunta 'halkın (üzerine)' (KT D 26) < *bodunda, kazgantok-in 'kazandı̆̆ı' (T55) < *kazgandok, ötüntok 'arz ettiğim' (T 15) < *ötündok (Tekin 2003: 75). 


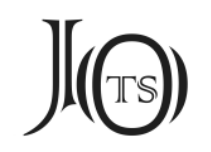

35.2 .

Alınma sözcüklerde ötümsüzleşme -g\# > -k\#: çorak 'çorak yer' < İran şōrag [Krş. Far. şōra 'tuzlu, çorak toprak'] (Tekin 2003: 71), Künüy 'iramak adı' (Tar. B5) < Mo. Huni, Huniyn (Tekin 2003: 249), Likäg 'kişi adı' (KT K12 < Çin. Lu xiang (Ölmez 1999: 62), kotay 'ipek, ipekli kumaş’ < Çin. goo dai (Ölmez 1999: 60), kunçuy 'prenses' < Çin. gong zhu (Ölmez 1999: 59), kung çu 'imparatorun kız1' (Tekin 2003: 249), kotay 'ipek, ipekli kumaş' < Çin. goo dai (Ölmez 1999: 60), Sadece /ç/ > /s / sızıcılaşması değil aynı zamanda gerilek ve uzak benzeşmeyle $/ \mathrm{k} /</ \mathrm{g} /</ \mathrm{\gamma} /$ değişmesi olmuştur; sök- 'diz çökmek' (KT D35) < çök- (Gürer 1990: 62) < AT *çöү-.

\section{3. $/ \mathrm{d} />/$ ç/}

küçüg 'iş güç' [işig küçüg birmiş] BK D8 < küdüg (Erdal 2004: 97), yukarıda benzeşme maddesinde de geçti. Ayrıca bk. aykırılaşma.

\section{Akıcılaşma}

\section{1. *\#d- > \#y-}

yagı (KT K8, yagin 'düşman, savaş' (MÇ K6) < *dagin (Tekin 2003: 78).

\section{2. *\#k- > \#-}

yul- 'yağmalamak' (BK D32) < yult- (IB 8) <* kāl- (Tekin 1975: 170).

\section{3. $*$ \#- -46 \#y-}

yir ‘yer, ülke' (KT G8) < *tir ‘İng. country’ (Tuna 1990: 260) ve devaminda 5 örnek daha var.

\section{4. $* / \mathrm{d} />-\tilde{\mathrm{n}} \#$}

koń 'koyun’ < *koni < *udu [Sümer \#øu = Türkçe \#ku/ka] (Tuna 1990: 267).

46 'Türkçenin y-ve s- lehçelerine ayrılmasına sebep olan sesin, pek çok Türkolog tarafından $\delta$ işareti ile gösterilen damaksıl, dişeler arası, sızıcı bir ses olması ihtimali daha yüksektir. Bu ses 'dç', 'dz' ‘ ts' vb gibi birkaç ünsüzü kendisinde barındırıyor olmalıdır. Birçok dilde böyle çift karakter taşıyan sesler vardır, örneğin Rusçadaki ц 'ts' sesi sözcük başlatabilen de bir sestir. Türkçede, genelde, ünsüzler tonsuzdan tonluya oradan ünlüye değişir, bazen de düşer. Türkçedeki bu genel eğilime göre y-, Illk Türkçe

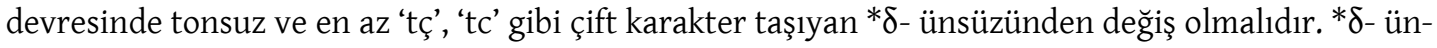
süzünün tonsuz şekilleri tarihi ve çağdaş Türk lehçeleri ile Türkçeden Moğolcaya geçmiş sözcüklerde bulunmakta ve Genel Türkçedeki y- 'ye denk gelmektedir' (Alibekiroğlu 2013: 692, 707). 


\section{$J(\Theta)$}

\section{5. $/+c ̧ />/+z /$}

Ekleşmede görülür. Üçüncü teklik kişi emir eki \{-zUn\}:-zun <-çun, türük bodun yok bolma-zun bodun bol-çun tiyin ... (KT D11) 'Türk halkı yok olmasın, (yeniden) halk olsun diye ...' .

\section{Aykırılaşma}

Benzeşmenin tam tersi olan, benzer seslerden kaçınılarak aynı cinsten iki sesin ayrılmasını yani ses itişmesini gidermek ve ses akışını sağlamak amacıyla oluşan aykırılaşmanın örnekleri benzeşmeye göre yazı dilinde daha nadir olarak görülür. Kısacası çoğunlukla yabancı dilden alınan sözcüklerde görülen aykırılaşma bir gramer birliğinde yer alan seslerin çıkış noktası ve söyleniş niteliği bakımından birbirinden uzaklaşmasıdır. Aykırılaşma da benzeşme gibi yön ve derecelerine göre tasnif edilebilir (Özçelik 2003: 139). Benzeşmeme ise ekleşmede görülen uyumsuzluktur. Aşağıda işlendi.

\section{1. $/ g />/ c ̧ /$}

ançola- '(bir büyüğe) bir şey takdim etmek, sunmak' (KT D32) < *ango 'hediye, ödül' (Tekin 2003: 87).

\section{2. $* \# \mathrm{~m}>\# \mathrm{k}$}

kal- / kāl- 'kalmak, umutsuz durumda kalmak' (Tekin 2003: 245) < *mal- 'kalmak' (Tuna 1990: 260) [14 örnek daha var].

\section{3. \#m- > \#g-}

$g u<m u$, eki üç bing sümüz kelteçimiz bar mu ne (T14). [Kalın sıradan tek şekli olduğundan ünlü uyumuna girmez. $m u>g u>w u>$ Korece $\bar{v}$ (Choi 2019: 287)].

\section{4. $/ \mathrm{d} />/$ ç/}

küçüg 'iş güç' [işig küçüg birmiş] (BK D8) < küdüg (Erdal 2004: 97), [söz başındaki \#k- ünüsüzünün etkisiyle yönüne göre ilerlek, derecesine göre uzak aykır1laşmadır]. Yukarıda bk /d/ > /ç/. 


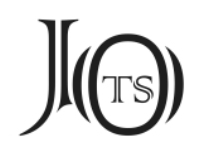

\subsection{Denazalizasyon (Aykırı Genizleşme)}

/y/ /g/:47 Köktürk işaretli yazıtlardaki sözcüklerde geniz ünsüzü /y/ yerine gırtlak ünsüzü /g/ yazılması 'aykırı genizleşme (denazalizasyon)' ye bağlı Oğuz Türkçesi özellikleri gösteren metinlerde baskın olmayan - bir ‘ağız özelliği'dir ve Köl Tigin ile Bilge Kağan başta olmak üzere, Uygur devresinin runik yazıtlarında Hotencenin Türkçeye etkisiyle görülür (Sertkaya 2014: 10); Teklik ve çokluk 2. kişi iyelik eklerinde geniz ünsüzü /y/ yerine girtlak /g/ ünsüzünün gelmesi (Tekin 1968: 92, 93). taş+ka, taş+1+ya [3. kişi iyelik ekinden sonra] (Ata 2011: 89149133129 122), kazgan- 'kazanmak' < *kaz-1-k+a-n- (Erdal 1991: 604) Kök. kazgan- 'kazanmak' k(i)mke il(i)g k(a)zg(a)nur m(e)n ‘Kime ülke kazanıyorum' (KT D9) (Demirci 2010: 139).

\subsection{Dissimilation (Başkalaşma)}

\subsection{1. $-\mathrm{y} \# \sim-\mathrm{g} \#$}

$\{+\imath \eta\}:$ tadık+ı çor+ıg boz [at] 'Tadık Çor'un boz (atı)' (KT D 32), [iyelik öbeğinin sahibini gösteren söz öbeğinin her iki üyesinde görülür.], (Tekin 2003: 107).

\subsection{2. $\{+\ln \}^{48}$}

$k(a) g(a) n(\imath) \eta+(\imath) n$ s(a)bin (a)lm(a)tin 'kağanın sözünü almadan (dilemeden)' (KT G9), kagan 'kağan' +(l) [2. tekil kişi iyelik eki] +in [ilgi (tamlayan) durumu eki: Bu $\mathrm{ek} / \mathrm{y} /$ iledir. Ancak 2. tekil kişi iyelik eki olan $+\eta$ 'den sonra geldiği için aykırılaşma (dissimilation) sonucu /n/'ye dönüşmüştür].

\section{Patlayıcılaşma}

Nitelik bakımından sızıcı olan bir ünsüzün patlayıcı hale gelmesidir. Alınma sözcüklerde görülür.

\footnotetext{
47 Daha önceki geniş bir irdelemede ünsüz değişmesi olarak adlandırılmıştır (Çağatay 1954: 15).

48 ‘íki ismin yan yana gelmesi sahipliği göstermesi açısından yeterli olmalı’ görüşünden yola çıkılarak /n/ ve /g/ sesleri ilgi (genitif) durum eki olmadan önce bulunma (lokatif) durum eki olarak kullanılmış, \{+nIn\} eki \{+In\} ilgi durumu ekinin yı̆̆ılmasıyla oluşmuş ve zamir /n/'si ise ilgi durum ekinin ek yı̆̆ılmasından sonra nazalleşmesiyle ortaya çıkmış olabilir (Özdemir 2019: 156 162).
} 


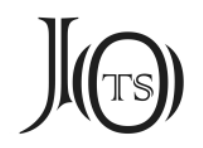

38.1. \#ş- > \#ç-

çorak 'çorak yer' < İran şōrag [Krş. Far. şōra 'tuzlu, çorak toprak'] (Tekin 2003: $71)$.

38.2. /j/ > -ç\#

Makaraç 'özel ad' (KT G13) < Skr. Mahārāja (Ölmez 1999: 64).

38.3. $/ \mathrm{sh} />/$ ç/

Berçik 'Fars, kavim adı' (KT K12) < Bärçik < Far. *Pārsi:k er 'Zerdüş Soğdlar' (Ölmez 1997: 178), biçin ‘maymun, y1l adı’ (KT KD) < Çin. fei-shen (Ölmez 1997: 179).

\section{Sızıcılaşma}

Ötümsüz, sürekli ve patlayıcı olan diş arası ünsüzü /ç/ ünsüzü ötümsüz, sürekli ve sızıcı diş ünsüzü /ş/ ile değişerek Kıpçakça özellik olan bu ses değişmesinin ilk emarelerinden olmalıdır (Gürer 2008: 381). Hatta Yakut Türkçesi tarihi devreleriyle de ilişkilendirilebilir (Gürer 1990: 62).

\section{1. \#ç > \#S}

sök- 'diz çökmek' (KT D35) < çök- (Gürer 1990: 62) < AT *çöү-.

\section{Ses Ayrışması}

Birleşik karakterdeki ünsüzler değişmeyle çözülür (İng. archiphoneme). Örnek: çıgan < çıgań 'yoksul'> çıgay (Kononov 1980: 33), ayrıca bk. ünsüz korunması.

\section{Dudak Ünsüzleri Arasında Değişme}

\subsection{Diş-Dudak Ünsüzlerinde Değişmesi}

\subsection{1. $\# \mathrm{f}>\# \mathrm{~b}$}

biçin ‘maymun, yıl adı' (KT KD) < Çin. fei-shen (Ölmez 1997: 179).

\subsection{2. \#f $>\# p$}

pur(u)m ‘Roma, Bizans' (KT D4) < Part. Frum, (Tekin 2003: 62).

\subsection{3. $/ \beta />/ \mathrm{p} /$}

apar 'Avar[lar]' (KTD 4) < Grek. Aßar (Tekin 2003: 72). 


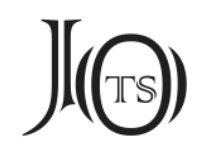

\subsection{4. $/ \mathrm{v} />/ \mathrm{b} /$}

ışbara ‘yüksek bir unvan’ (KÇ D10) < Sansk. İ́sara ‘lord, prens’ (Tekin 2003: 72).

\section{2. Çift Dudak Ünsüz Değişmesi}

$/ \mathrm{m} />/ \mathrm{b} /$ : buñsız 'dertsiz, kaygısız, sıkıntısız' < buñ 'dert, sıkıntı' (Tekin 2003: 83) < mung 'sıkınt1, 1stırap, mihnet' (Soydan 2017: 880), Ana Altayca düşünüldüğünde $/ \mathrm{m} />/ \mathrm{b} /$ değişmesi daha arkaik düşünülmektedir (Tekin 1992: 83) ve bir /*m/ ünsüzü tasavvuru vardır, Tk. beggü 'ebedî' < Alt. *mengü (Tuna 1983: 2425 28), matı ‘sadık’ BG K14 (Tekin 2003: 250) < Mo. batu (Ölmez 1999: 65),

Gerilek benzeşme ve bulaşma başlığı altında işlenirken dip notlarda da açıklama yapild.

\section{Akıcı Ünsüzler Arasında Değişme}

\section{1. $/ \mathrm{ng} />/ \mathrm{n} /$}

kunçuy 'prenses' < Çin. gong zhu (Ölmez 1999: 59), kung çu 'imparatorun kızı' (Tekin 2003: 249), ng > y > n yönündeki ses değişmesinde çıkış yerine göre arka damak, ses tellerinin titreşimine göre ötümlü, temas derecesine göre akıc1, çıkış yoluna göre genizsi (nazal) /y/, çıkış yerine göre diş (kökü) /n/'si olur.

\section{2. *\#ń > \#y}

IT *\# ${ }^{49}>$ AT *\#y (Ceylan 1997: 41) > ET \#y: yar- 'yarmak' (IB 40) <*dar- 'Alm. splaten, yarmak' (Tuna 1990: 260) ve devaminda 9 örnek daha var. yılan 'yılan' IB 8 (Tekin 2003: 259) <* ńil- 'kaymak, sürünmek' +lon (<Çin. loon ) [fiilden isim eki -an şeklinde türemiş olması gereken bu sözcük, arslan, qaplan, sirtlan, bulan, qulan, vb. gibi birçok hayvan ismindeki \{-lan\} ekinin kaynağını oluşturmuştur. (?)], íT

49 'Türk dillerinde (yazar, Türk lehçeleri için diller, terimini kullanmaktadır.) y- ile veya y- 'den gelişen fonemlerle (c-, ç-, j-, s-, ś-) başlayan sözcükler, Moğolca ve Mançu-Tunguzcada birincil *d-, *c-, *y-, *n-, *ń- ile başlayan sözcüklere denk gelirler. Moğolca ve Mançu-Tunguzca *d-, *c-, *y-, *n-, *ń- fonemlerini korurken, daha İlk Türkçe döneminin ikinci aşamasında (illk Türkçe 2) bu fonemler y- ile bir ve aynı olmuşlardır. Söz konusu fonemlerin, İlk Türkçenin birinci döneminde korunmakta olduğu, İlk Türkçeden Macarcaya geçmiş olan ödünç sözcüklerden anlaşılmaktadır: Mac. nyár [ńar] 'yaz' < İT (1) 'ńār²; Çuv. śur 'yaz' < *cār < *yār < *nār²; Trkm yāz, Yak. sās 'yaz'; Mo. niray 'yeni doğmuş, taze' < ńār2 (aynı anlamda); Ma. ńarxun ‘taze, yeşil’ ; Ko. ńyerim ‘yaz' (Ceylan 1997: 39). 


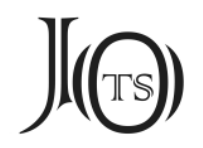

*\#ńilom < EBT *\#dilom (Dilaçar 1953: 74) > AT *\#yilan/*\#yìlān > ET \#yılan [bk. ve krş. yıla:n yılı 'Türklerde 12 yıldan birinin adı'] (Biray 2014: 30) ${ }^{50}$ ve (Alibekiroğlu 2013: 689). Ayrıca yıg- 'bir araya getirmek' (Tekin 2003: 259) < nigin 'yığın' [6 örnek daha var.] (Tuna 1990: 260).

\section{3. $/ 1 />/ \mathrm{r} /$}

balbal balbar 'öldürülen düşmanın taş heykeli' (Tuva III4) < Mo. barimal barimal (Tekin 2003: 239). Ayrıca bk. gerilek benzeşme.

\section{Süreksiz Ünsüzler Arasında Değişme}

Ötümsüz, patlayıcı ve süreksiz olan diş-arası ünsüz değişmesi görülür.

\section{1. \#t > \#ç}

Çor 'yüksek unvan' tor $<\varnothing \varnothing$ tor $<*$ [ba]tor ( $<$ *bagator) 'bahadır' (Alyılmaz 2013: 46).

\section{Sesbirimsel Boşlukta Yarı Kapantılı Ünsüz Yerine Sürekli Ünsüz Tercihi}

Sesbilgisi boyutunda sözcüksel kopyalamada, sesbirimsel boşluklar vardır. Kaynak dilde mevcut olan bir sesin hedef dilde mevcut olmayışıyla ortaya çıar (Sar1 2013:9).

\section{1. \#ts $>$ \#s}

Telaffuz güçlüğünü gidermek için alınma sözcüklerin başında yarı kapantılı /ts/ ünsüzünde görülür; sin 'mezar' (Tar. G5) < Çin. ts'in. (Tekin 2005: 252), Lisün 'kişi adı' BK G11 < Çin. Li-ts’ün < dz'įwän < li quan (Ölmez 1999: 68).

50 Ana Türkçedeki y- çok eski bir devirde c'ye çalan ön damak d'si değerindedir (Dilaçar 1953: 74). Türk dilinde ön sesteki y- lehçelerde ' $y-$-, n-, d'-, t'-, s-, j-, c-, ç-, ts-, dz-, z-, -ø' (Çuvaşça'da ś-) değişmelerine uğrar (Tuna 1983: 32). Saha (Yakut) Türkçesinde erien üön 'yılan' (Biray 2014: 29) < * d1l+lōn [kelime başında d- > y- >s > , kelime içinde ŞAZ : LíR denkliğiyle (çift başlı yılan düşünüldüğünde dualiteyle) ş $<\mathrm{l}>\mathrm{r}>\mathrm{z}>\mathrm{s}$ ses gelişimi dikkate alınınca $\mathrm{l}>\mathrm{r}$ ünsüz değişmesi, kelime sonunda ise ien [üön] $<$ an < +lan <*+lōn ekinde (Özbek Türçesindeki ilån düşünüldüğünde Çinceden alınan yıl adı da olan masal varlı̆̆ı loon > lon > lån) diftong tekrarıyla önce alçalma /ie/ sonra /üö/ yükselme görülür]. Birleşik kelime: erien ӥӧn эриэн үөн < erien 'yılan' üön 'kurt' [= eriyen bars (Wallace 2020: 377)], [bk. tr.wiktionary.org/wiki/Yөн\#], < Moğolca ödünç kelime 'Mongolian loanword' eriyen, Эрээн хот < Çince 二连 浩特 erenhot 'ağzından ateş çıkan ejderha' [bk. İng. snake, Sakha erien üön, https://wold.clld.org/word/, en.wikipedia.org/wiki/Erenhot]. 


\section{J(G)}

\section{Yakın ses Konulması}

Aşina [etimolojisi için bk. sonuç bölümü, Karluk ağzı] gibi eksonim (yabancıların taktığı isim) olan sözcüklerde görülür (Çalışkan 2018: 21).

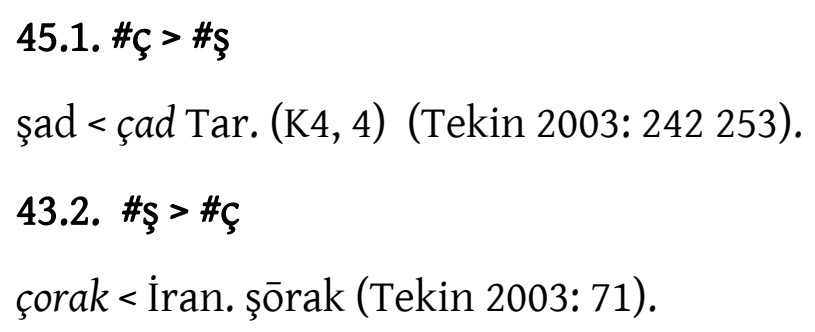

\section{Asalak ünsüz (Parasitical Consonant) Görülmesi}

Bazen asalak (parasitical) diş kökü (alveolar) akıcı (sonant ‘ötümsüz karş1lığı olmayan ötümlü') ünsüzler /l, r, n/'yi damaksıl (velar) olan ötümsüz diş kökü /t/ ünsüzü takip eder. Ötümlü /d/ şekli (DLT köndgär- 'göndermek' < *kön(i)+gär) Karahanlıcada görülecektir. Burada titrek /r/ ünsüzünden sonra tezahür etmiş: olort- 'tahta oturtmak' T1 (Tekin 2003: 250) < olor-, daha sonra Eski Uygurcada amırtgur- 'sakinleştirmek' < *amïr-gur-, gibi örnekler çoğalır (Erdal 2004: 114).

\section{Sonuç}

Dilbiliminde seslerin işlevsel özelliklerini dil sisteminde tahlil etme durumu, tarihi fonolojiyi meydana getirdi. Köktürk işaretli seslere özel araştırma gereksiniminin duyulması, sesle ilgili oluşan iki bilim (fonetik, fonoloji) alanından tarihsel fonolojinin konusu olmuştur. Telaffuzla ile ilgili bilim, fizik olaylarla alakalıdır. Fonetik fen bilimleri yöntemlerini esas alır. Dilbilimindeki sesle ilgili bilim yani tarihsel fonoloji ise tam aksine yalnız dilbilim yöntemleri ve kurallarına, sosyal bilimlere dayanır. Konuşmadaki sesle ilgili bilim fonetik, dilbilimde ise sesle ilgili bilim fonoloji olarak adlandırılır. Tarihsel fonoloji, ses değişmelerini ayrı ayrı değil, diğer seslerle bağdaştırarak inceler. Bütün fonetik sistemi incelemeyi hedefler. Araştırma sonuçları klasik fonetik olaylara dayanır. Japon, Moğol ve Türk dillerinin karşılaştırması ile Türk dili ve lehçelerini araştırma s1rasında Köktürkçedeki ses değişme olayları büyük öneme sahiptir. Aşağıda Köktürkçedeki 5 temel belirleyici başlık altında yukarıdaki ses olayları özetlenerek birkaç misalle sınıflandırılmıştır: 


\section{J(৫)}

\section{Anlam Belirleyiciliğine Göre}

Etimonun 'tanımlanamayan, alışılagelmedik biçimin' ilk ve lafzi manası 'etimolojik anlam', proto dilde gerçekte kullanılan anlamına ise 'ilk anlam' veya 'asli/birincil anlam' denildiği belirtilmiştir (Stachowski 2011: 93). Türkçe için proto dil Ana Türkçedir.

\subsection{Anlam Değişikliğine Sebep Olma}

Dilin ayırt edici ses özelliği Eski Türkçede vardır. Türk dili tarihi boyunca Türkçenin sesbirim sayısında değişiklikler olmuştur. Örneğin, Türkçe sözcüklerdeki ünlü niceliği, Ana Türkçe ve kısmen Eski Türkçe için ayırt edicidir (Eker 2007: 25). Mesela, aşağıda görüleceği üzere /ā/, /a/; /é/, /e/; /y/,/n/ birer sesbirimdir yani anlam ayırt edicidir.

\subsection{1.}

Uzun ünlünün korunması: āç 'aç, tok olmayan' (BK D38), aç- 'açmak' (T28); $\bar{a} t$ 'ad, unvan' (KT D7), at 'at, beygir' (KT D33).

\subsection{2.}

Anlam ayırt edici e/ ünlüsü: Ünlü ses birimin nitelik karşıtlı̆̆ı (farklı çıkaklarda oluşması) ile açık e (ä) ve kapalı (é) fonemiktir (Eker 2007: 33); äl(ig) 'el' ve el [él] 'il, devlet, ülke, memleket, halk' (Tekin 2003: 243).

\subsubsection{Eşgösterenlik}

kalın 'kalın; kalabalık', kalı 'başlık parası' < kal- 'kalmak; umutsuz durumda olmak'< ka- 'eklemek, koymak'.

\subsection{Anlam Değişikliğine Sebep Olmayan Ses Olayları}

Anlam olayları dilin daha sonraki evrelerinde gelişecektir. Ses olaylarının çoğunda anlam değişikliği olmaz. Söz başında patlayıcılaşma, söz içinde ünlü k1salması ve söz sonunda ötümsüzleşmeye örnek olan şu sözcükteki değişmeler gibi; çorak 'çorak yer' < İran şōrag. 


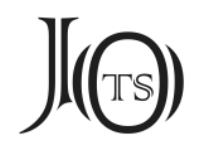

\section{Karakteristik/Belirgin Olmasına Göre Ses Olayları}

\section{1. İşlek Olanlar}

Söz başında (bol- 'olmak', bar 'var'), söz içinde içinde (ebir- 'evirmek') ve söz sonunda (eb 'ev') /b/ ünsüzünün korunması, $d /$ 'nin ve /g/ korunması (edgü 'iyi'), ön damak nazal 'genizsil' /y/ ve ince $/ \mathrm{n} /</$ ń/ > /y/ palatal 'damak') ünsüzünün

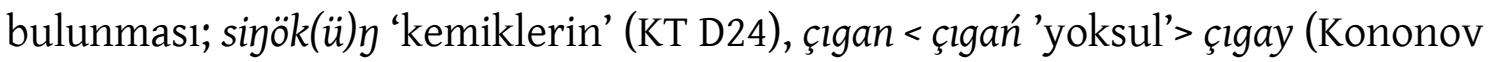
1980: 33), dudak ve ünsüz uyumu güçlü değildir: bugu ölürtüm 'geyik öldürdüm', böri ölürdüm ‘kurt öldürdüm' (Aydın 2013: ), Bilir biligim bilmez teg boltı. 'Bilir aklım bilmez gibi oldu (delirecek gibi oldum)' (KT K101).

\section{2. İşlek Olmayanlar}

Birincil uzun ünlünün korunması aaç 'aç, tok olmayan, acıkmak', aat 'ad' (Foy 1900: 192 193), \#t > \#ç: Çor 'yüksek unvan' tor < ØØtor <**[ba]tor (<*bagator) 'bahadır' (Alyılmaz 2013: 46) gibi.

\section{Art Zamanlı Olmasına (Kaynak Dile) Göre Ses Olayları}

\section{1. İlk Türkçe: LIR Özelliği ${ }^{51}$}

\subsection{Ana Türkçe: Birincil Uzun Ünlü v̄/.}

\subsection{Yabancı Diller}

Daha çok Çince'den alınan sözcüklerde görülür.

\section{Betimsel Gramere Göre Ses Olayları}

\section{1.}

Nöbetleşme ile varyantların görülmesidir.

51 'Zetasizm-sigmatizm gibi bizi daha eskiye götürecek ses değişimleri söz konusu ise, burada Ana Türkçeden daha geriye gideriz; çünkü Ana Türkçede /r/ ve /l/ sesleri bulunmaz. Çuvaşça dişında bütün Türk dilleri Ana Türkçeye gider. Ana Bulgarcadan gelişen Çuvaşça, Ana Türkçeden önce Türk dillerinden ayrılır. Eğer Ana Türkçede /r/ ve /l/ olsaydı bütün Türk dillerinde de olması beklenirdi. Ama /r/ ve /l/ sesleri Çuvaşça dişındaki hiçbir Türk dilinde olmadığı için, Çuvaşça bu özelliği ile Ana Türkçeye değil, i̇lk Türkçeye ait veriler sunar' (Yılmazkaya 2017: 152). 


\section{$J(\Theta)$}

4.2 .

Ekleşme sırasında görülen ses olaylarıdır. oglın kişisin bulna[...] 'oğlunu, karisinı esir edip [...] (Ih B 5) (Demirci 2010: 131), ogl+<<ogl <ogul 'evlat'; bulna- 'esir etmek' < bulun 'esir' (KÇ B5) (Tekin 2003: 241).

\section{3.}

Eklerde görülen ses olaylarıdır. 3. kişi iyelik eki $\{+(s) I(n)\}$ art ünlülü sözcük-

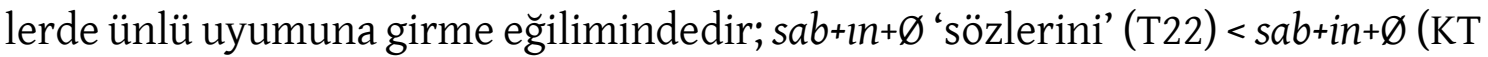
K9), $u+\sin +\varnothing$ 'uykusunu' (T19) < * $\overline{\mathrm{u}}+\sin +\varnothing$; eçüm apam törü+sin+çe 'atalarımın dedelerimin töresince' vb. (Ata 2011: 86); kazgantok+in 'kazandığ1' (T55) <*kazgandok. Üçüncü teklik kişi emir eki \{-zUn\}'un ekleşmesinde görülür; -zun <-çun, türük bodun yok bolma-zun bodun bol-çun tiyin ... (KT D11) 'Türk halkı yok olmasın, (yeniden) halk olsun diye ...' .

\section{Karşılaştırmalı Gramere Göre Ses Olayları}

\section{1 .}

Çağdaş uzak lehçelerin (Çuvaş ve Yakut) dışında ağızların başlangıcı: Eski Doğu Türkçesi (ŞAZ) ağızları; Karluk ${ }^{52}$ (Karluk bodun 'karluk boyu' BK D29, Orhon Türkçesinin yazı dilinin temel alındığı ağız), oğuz (\#b-, b(ä)n, bini ‘beni’ (T) (Gabain 2013: 133) ve Kıpçak ağızları (ç > s, O-O vb)..$^{53}$

\section{2 .}

Arkaik (LIR ve \#s- grubu) ağız özelliğinin izi: kıl-, kış- ve sök- gibi Orhon Türkçesinden önceki dönemde Türk dilinin Çuvaş ve Yakutlarla birlikte olduğu döneme işaret eder.

52 Karluk teorisine göre bugünkü Karluk/Doğu grubu olan Özbek ve Çağdaş Uygurların atası Köktürklerin, Uygurların ve Karlukların menşeinin dayandığı sözcük: Aşinas Karabalgasun yazıt 1 < Çince A-shih$n a$ 'kurt neslinden gelen Na-tou-liu Şad'ın on karısı kabile ismi' < Hotence hişşana 'demircinin oğlu' [Çin kaynaklarında JuanJuan Kağanı A-na-kui'nin Bumın'ı 'demir işlerimde çalışan bir kölemsin’ diye tahkir etmesi de bir kanıttır.] (Çalışkan 2018: 23).

53 Tarihi Türk dünyasının en büyük boy teşkilatlarından olan Karluk, Oğuzlar ve Kıpçaklar boyları birbirlerinden çok belirgin coğrafî, siyasî ve dilsel sınırlarla ayrılmamaları ve Avrasya coğrafyasında asırlar boyu devam eden hareketlilikleri sebebiyle, Türk yazı dili ve lehçeleri devamlı karşılıklı olarak birbirlerine tesir etmişlerdir (Özyetkin 2006: 8). 


\section{$J(\Theta)$}

\section{Öneriler}

Sonuç bölümündeki 5 temel belirleyiciye göre Köktürk işaretli metinlerinin ses bilgisi ayrı ayrı irdelenebilir. Genel olarak 3 durum vardır:

1. Sadece metinin içerisinde tasrife dayanan tasviri yani betimlemeli olarak yapilan ses olayları,

2. Art zamanlı olarak kaynak dillere (Ana Altaycaya - Moğolca, Mançu ve Tunguzca, Korece, Japoncaya -, İlk Türkçeye ve Ana Türkçeye) göre ses olayları,

3. Eş zamanlı olarak Eski Uygur ve Karahanlı; Eski Bulgar, Peçenek ve Hazar Türkçesine göre ses olayları çalışılabilir.

\section{Değerlendirme}

Yukarıdaki 46 ana madde olarak tespit edilen ses olaylarında tespit edilemeyen bir iki eksiklik olabilir ve makalenin hacmini artırmamak için sınırlı tutulan örneklere onlarcası eklenebilir. Burada çok bilinen ses olaylarına yeni tespit edilenler de eklendi. Böylece Türk lehçeleri ve ağızları üzerine yapılacak çalışmalara ses olayları bağlamında bir küçük ışık tutulmaya çalışıldı.

\section{Kisaltmalar}

$\mathrm{AT}=$ Ana Türkçe.

$\mathrm{B}=$ Bat1.

$\mathrm{BK}=$ Bilge Kagan yazit 1 .

Çuv. = Çuvaş Türkçesi.

$\mathrm{D}=$ Doğu.

DLT = Dîvânu Lugâti't-Türk.

$\mathrm{ET}=$ Eski Türkçe.

ETT $=$ Eski Türkiye Türkçesi.

$G=$ Güney.

$\mathrm{IB}=\operatorname{Irk}$ Bitig.

İT = İlk Türkçe.

$\mathrm{K}=$ Kuzey. 


\section{$J(\Theta)$}

Kök. = Köktürkçe.

KT = Köl Tigin yazıtı.

Kzk. = Kazak Türkçesi.

MÖ = Milattan Önce.

Mo. = Moğolca

$\mathrm{T}=$ Tuńukuk yazitı.

Yak. = Yakut Türkçesi.

\section{Kaynakça}

AKAR, A. (2006). Türk Dili Tarihi, İstanbul: Ötüken Neşriyat.

AliberiRoĞLu, S. (2013). “Türkçede Ön Ses y”, Turkish Studies, 8/1: 685-710.

Alimov, R. \& K. TABALDiev (2005). "A Newly Found Old Turkıc Runic Inscription on a Boulder From Talas", Journal of Turkish Studies, 30/1:121-125.

Alyilmaz, C. (2013). "Karı Çor Tigin Yazıtı”, TEKE: Uluslararası Türkçe Edebiyat Kültür Eğitim Dergisi, 2/2:1-61.

ALYILMAZ, C. (2018). “Köktürkçe ve Eski Uygurca Dersleri Adlı Kitaptaki Orhun Yazıtları'na Ait Metinlerin Kaynağı Hakkında”, TEKE: Uluslararası Türkçe Edebiyat Kültür Eğitim Dergisi, 7/1: 1-52.

ARIKoĞLu, E. (2007), “Greenberg'in Avrasyatik Dil Teorisi ve Türkçe”, Dil Araştırmaları Dergisi, 1/1: 109-114.

ATA, A. (2017a). “Köktürkçe Gramer (Söz Yapımı)/Söz Yapımı”, (Ankara Üniversitesi Açık Ders Malzemesi).

ATA, A.(2011). Orhun Türkçesi, Ed. G. GüLSEvin \& M. M. Tulum, Eskişehir: Anadolu Üniversitesi Açıköğretim Fakültesi Yayını.

ATA, A.(2017b). “Köktürkçe Gramer (İsim, Zamir)/İsim, Zamir”, (Ankara Üniversitesi Açık Ders Malzemesi).

ATMACA, E. (2013). “Eski Oğuz Türkçesinden Günümüz Türkiye Türkçesine Eşgösterenlilik “, Dil Araştırmaları, 12: 117-138.

Aydemir, A. (2009). “Oğuz Adı Üzerine”, Türk Dünyası Tarih Dergisi, 274: 56-59. 


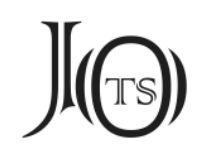

AYDIN, E. \& G. GÜNER (2007). “Kök Türk Harfli Metinler ve Kök Türklerle İlgili Türkiye'de Yayımlanmış Çalışmalar Bibliyografyası (Deneme)”, Türk Dili Araştırmaları Yıllı̆̆ Belleten, 2007/I: 33-82.

AYDIN, E. (2013). “Yenisey Yazıtlarındaki Tek Örnekler”, Türkbilig, 26: 37-49.

AYdin, E. (2015). Orhon Yazıtları (Köl Tegin, Bilge Kagan, Tonyukuk, Ongi, Küli Çor), (3. Baskı), Konya: Kömen Yayınları.

Aydin, E. (2019). “Türk Runik Bibliyografyası'na Ek I”, Journal of Old Turkic Studies, 3/1: 6-40.

BARUTÇU-ÖzÖNDER, S. (1992). “Eski Türkçe Kaltı ve Nelük Kelimeleri”, Türkoloji Dergisi, 10/1: 71-76.

BARUTÇU-ÖzÖNDER, S. (2002). “Türk Dilinin Tarihî Dönemleri Üzerine Birkaç Söz”, Türkbilig, 3: 203-210.

BAŞDAŞ, C. (2014). “Türkçede Üçüncü Şahıs İyelik Eki ve Zamir N’si”, The Journal of Academic Social Science Studies, 30: 147-161.

BìraY, N. (2014). “Söz Varlığımızda Yılan”, Avrasya Terim Dergisi, 2/1: 25-49.

BLAŽEK, V. (2019). Altaic Languages: History of Research, Survey, Classification and a Sketch of Comparative Grammar (in Collaboration With M. SCHWARZ \& O. SRBA), Brno: Masaryk University Press.

Bombaci, A. (1974). “On the Ancient Turkish Title Şad”, Guruijamanjarika, Studi in Onore di Giussepe Tucci, Napoli: 167-193.

BRENDEMOEN, B. (1998). “Turkish Dialects”, The Turkic Languages, Eds. L. JoHANSON \&É. Á. CSATÓ, London-New York: Routledge.

CEYlan, E. Y. (1991). “Ana Türkçede Kapalı E Ünlüsü”. Türk Dilleri Araştırmaları, 1: 151-165.

Ceylan, E. Y. (1992). "Illk Türkçe *d Foneminin Çuvaşça ve Macarcada Gelişimi”, Türk Dilleri Araştırmaları, 2: 109-120.

CEYlan, E. Y.(1997). Çuvaşça Çok Zamanlı Ses Bilgisi, Ankara: Türk Dil Kurunu Yayınları.

CHoI, H.-W. (2019). Türkçe, Korece, Moğolca ve Mançu-Tunguzcanın Karşılaştırmalı Ses ve Sekil Bilgisi, Ankara: Türk Dil Kurumu Yayınları. 


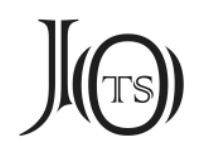

Clauson, S. G. (1972). An Etymological Dictionary of Pre-Thirteenth Century Turkish, Oxford: Oxford University Press.

CoşKUn, M. V. (2011). “Standart Türkçede Ses Olaylarının Sebep-Sonuç İlişkisi Çerçevesinde Yeniden Sınıflandırılması", 38. Icanas, Türk Dil Kurumu Yayınları, Ankara: 347-367.

ÇAGATAY, S. (1954) “Türkçede ñ g Sesine Dair”, Türk Dili Araştırmaları Yıllı̆̆ı Belleten 1954: 15-30.

ÇALIŞKAN, M. (2018). “A-Shih-Na Kelimesinin Etimolojisine Dair Yeni Bir Fikir”, STAD: Sanal Türkoloji Araştırmaları Dergisi, 3/1: 21-24.

ÇETiN, E. (2008). On Üçüncü Yüzyıl Öncesi Türkçesinde Soru, Çukurova Üniversitesi Sosyal Bilimler Enstitüsü Türk Dili ve Edebiyatı Ana Bilim Dalı, Adana. (Yayımlanmamış Doktora Tezi)

Demir, E. (2014). “S. Gerard Clauson'un Etmolojk Sözlügünde Geçen Sağlık ve Tıpla İlgili Kelimeler”, Uluslararası Sosyal Araştırmalar Dergisi, 7/31: 131-148.

DEmirci, Ü. Ö. (2010). Eski Türkçede Fiiller, Marmara Üniversitesi, Türkiyat Araştırmaları Enstitüsü, Türk Dili ve Edebiyatı Anabilim Dalı, Türk Dili Bilim Dalı, İstanbul. (Yayımlanmamış Doktora Tezi)

DilaçAR, A. (1953). “Batı Türkçesi”, Türk Dili Araştırmaları Yıllığı Belleten 1953: 7392.

Doerfer, G. \& S. TEZCAN (1980). Wörterburch des Chaladsch (Dialekt von Charrab), Budapest: Akadémie Kiadó.

EKER, S. (2004). “Talat Tekin, Makaleler 1, Altayistik (Yay. Hazırlayanlar: Emine Y1lmaz-Nurettin Demir), Grafiker Yayıncılık:11, Araştırma İnceleme Dizisi: 5, Ankara 2003, Xv1 + 384 S.”, Bilig, 29: 228-235. (Tanitma)

EKER, S. (2006). Çağdaş Türk Dili, Ankara: Grafiker Yayınları.

EKER, S. (2007). “Türkçenin Sesbirimleri ve Belirgin Altsesbirimleri”, İlmî Araştırmalar, 24: 23-42.

EKER, S. (2010). “Orhon Yazıtları: İran Dilleri İle İlk Temaslar ve Benzer Birkaç Öge Üzerine”, “Orhon Yazıtlarının Bulunuşundan 120 Yıl Sonra Türklük Bilimi ve 21. Yüzyıl” Konulu III. Uluslararası Türkiyat Araştırmaları Sempozyumu (26-29 Mayıs 2010), Bildiriler Kitabı I, Ed. Ü. Ç. ŞAVK, Hacettepe Üniversitesi Basımevi, Ankara: 321-332. 


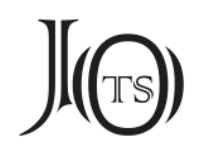

ERALTAY, S. (2019). “Türkçede Ben ve Sen Zamirlerinin Kök Değiştirmesi Üzerine”, Balıkesir Üniversitesi Sosyal Bilimler Enstitüsü Dergisi, 22/41:37-46.

ERASLAN, K. (2000). "Eski Türkçede Yönelme (Dativ) Hâli Ekinin Yap1, Fonksiyon ve İfadeleri”, İstanbul Üniversitesi Türk Dili ve Edebiyatı Dergisi, 29: 67-76.

ERDAL, M. (1991). Old Turkic Word Formation, a Functional Approach to the Lexicon I-II, Wiesbaden: Harrassowitz Verlag.

ERDAL, M. (2004). A Grammar of Old Turkic, Leiden Brill.

ERKoç, H. İ. (2018) Çin ve Tibet Kaynaklarına Göre Göktürk Mitleri”, Belleten, 293: $51-82$.

ERsoy, H. Y. (2017). “Türkçede Ses Düşmesi/Hece Kaynaşması Problemi: Başkurt Türkçesi Örneği”, Dil Araştırmaları, 20: 35-48.

Esin, E. (1978). “İslâmiyet’ten Önceki Türk Kültür Tarihi ve İslâm’a Giriş”, Türk Kültürü El Kitabı II, (Cilt I/B'den Ayrı Basım), İstanbul: İstanbul Üniversitesi Edebiyat Fakültesi Matbaası.

For, K. (1900). “Türkische Vocalstudien”, Mitteilungen des Seminars für Orientalische Sprachen, 3: 180-217.

GabAin, A. von (2013). "Eski Türkçede Zamirler”, Çev. B. AKçALI, Türk Dili Araştırmalar1 Y1llı̆̆ Belleten, 61/1: 131-142.

GoldEN, P. B. (2018). “Ok ve Ogur Oguz”, Dokuz Oğuzlar ve Oğuzlar Üzerine Araştırmalar, Çev. H. İ. ERKoç et al. Gece Kitaplı̆̆ı, İstanbul: 9-64.

GÖMEÇ, S. Y. (2006). “Şadapıt Unvanı Hakkında”, Bilge, 48: 11-15.

GÜLENsoY, T. (2007). Türkiye Türkçesindeki Türkçe Sözcüklerin Köken Bilgisi Sözlüğü I-II, Ankara: Türk Dil Kurumu Yayınları.

GÜLSEVIN, G. (1994). “Göktürk Anıtları İle Yaşayan Üç Lehçemizin (Çuvaş Türkçesi, Halaç Türkçesi, Yakut / Saha Türkçesi) Tarihî İlgi Düzeni”, Türk Dili Araştırmaları Yıllı̆̆ı Belleten, 1990: 55-64.

GÜLSEVIN, G. (2008). “Türkiye Türkçesi Ağ1zlarında Kıpçakça Denilen Unsurlar Üzerine 2: ç > ş Değişmesi”. Turkish Studies, 3/3: 378-387.

GüNEŞ, S. (2002). Türk Dil Bilgisi, İzmir: Altındağ Matbaası. 


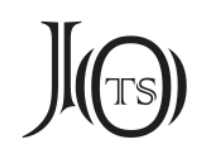

GÜVEN, M. (2016). “Kelime Tarihi ve Enkliz “Sığınım”lı Kelimelerin Türkçenin Kelime Tarihindeki Yeri”, Turkish Studies, 11/20: 265-290.

HACIEMinoĞLu, N. (1992). Türk Dilinde Edatlar, İstanbul: Millî Eğitim Bakanlığı Yayınları.

HaciYev, H.(2010). "Bir Emevî Vâlisi Ve Komutanı: Mesleme B. Abdülmelik B. Mervân Abdülmelik b. Mervân”, İstem, 8/15: 111-142.

HAYIRSEVER, H. (2018). “Talat Tekin ve Türk Dillerinde Birincil Uzun Ünlüler”, Talat Tekin ve Türkoloji, Ed. E. YILMAZ et al. Nobel Yayınları, Ankara: 267-283.

HAZAR, M. (2003). “Türk Lehçelerindeki Sözcüklerle Kaynaşmış Bir Çokluk Eki +(I)z Üzerine”, Türk Dünyası Dil ve Edebiyat Dergisi, 15: 131-141.

İLHAN, N. (2017). “Öksüz Öğüt Üvey Kardeş mi?”, Turkish Studies, 6/1: 473-481.

İNCE, Y. (2019). "Sebep ve Sonuçlarıyla Tarihî Türk Lehçelerinde $t>d$ Sedalılaşması”, Sosyal Bilimler Dergisi, 6/33: 131-142.

İРEK, B. (2016). “Türkiye Türkçesinde Enkliz (Eğilti)”, Atatürk Üniversitesi Türkiyat Araştırmaları Enstitüsü Dergisi, 57: 1535-1544.

KARADEMiR, F. (2016). “Türk Dilinin Tarihî Dönemlerini Adlandırma Sorunu”, TEKE: Uluslararası Türkçe Edebiyat Kültür Eğitim Dergisi, 5/2: 545-564.

KARAKURT, D. (2017). Türkçe Sözcük İncelemeleri Türk Dillerinden Seçilmiş Kelimelerle. (E-Kitap)

KLAŞTORNIY, S. G. (1969). Drevnetürkskaya Nadpis'na Kamennom Izvayanii iz Çoyrena, Pam'atniki Pis'mennosti i Kul'turi Narodov Vostoka, Moskova.

Kononov, A. N. (1980). Grammatika Yazıka Tyurkskix Runiçeskix Pamyatnikov (VII-IX. vv)], Leningrad: Nauka.

KorkmAZ, Z. (2003). Türkiye Türkçesi Grameri (Şekil Bilgisi), Ankara: Türk Dil Kurumu Yayınları.

Lampropoulou, M.(2017). "The Verb Forming Suffix -İzo and its Similative Meaning", 22nd International Symposium on Theoretical and Applied Linguistics Istal, 22: 339-357.

MAKi, K. (2017). "On The Loss of the Directive Case in Turkic Languages", Yyu The Journal of Social Sciences Institute, 1/2:1-8 


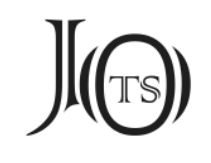

Mermer, A. (2009). Dil ve Edebiyat Türkler ve Türkçe Türkçenin Tarihi Gelişimi, Ankara: Kültür ve Turizm Bakanlığı Yayınları.

NAlBANT, B. Ö. (2018). “Kür/Kül «Cesur, Kahraman〉 Sözcüğü Üzerine”, Türkbilig, 35: $155-164$.

OKçU, C. (2019). “Kırgız Türkçesindeki Farsça Yapım Eklerinin Türkçenin Fonetiği İle Olan İlişkisi”, Sinop Üniversitesi Sosyal Bilimler Dergisi, 3/2: 221-230.

ÔsAwA, T. (2011). Eski Türk Devletinin Asıl Soyadı Ashina mı, Yoksa Ashinas mi?", Mahmūd al-Kāşgarînnin 1000. Doğum Yıldönümü Dolayısıyla Uluslararası Dîvānu Lugāt't-Türk Sempozyumu (5-7 Eylül 2008), Ed. H. Develi et al. Kitap Matbaası, İstanbul: 253-288.

ÖLmEz, M. (1995). “Eski Türk Yazıtlarında Yabancı Öğeler (1)”, Türk Dilleri Araştırmalar1, 5: 227-229.

ÖlmEz, M. (1997). “Eski Türk Yazıtlarında Yabancı Öğeler (2)”, Türk Dilleri Araștırmalar1, 7: 175-186.

ÖlmEZ, M. (1998). “Eski Uygurca Odug Sak İkilemesi Üzerine”, Türk Dilleri Araştırmalar1, 8: 35-47.

Ölmez, M. (1999). “Eski Türk Yazıtlarında Yabancı Öğeler (3)”, Türk Dilleri Araştırmalar1, 9: 59-65.

ÖzçELIK, S. (2002). “Aykırılaşma Terimi, Tanımı ve Örneklerinin Tasnifi Üzerine”, İlmî Araştırmalar, 14: 131-144.

ÖzDEMiR, H. (2019). “Eski Türk Yazıtlarında (Tonyukuk, Köl Tegin, Bilge Kağan, Ongi, Küli Çor) İlgi Durum Eklerinin Kullanımları ve Kökenleri Üzerine”, Karadeniz Araştırmaları, 16/61: 154-165.

ÖZEK, F. (2013). “Tarihî Türk Lehçelerinde Uzun Ünlülere Bağlı Olarak Oluşmuş Ses Olayları", The Journal of Academic Social Science Studies, 6/4: 649-666.

ÖzTÜRK, J. (2017). “Türk Dilinde Daha Çok Çaba İsteyen Değişimler”, TEKE: Uluslararası Türkçe Edebiyat Kültür Eğitim Dergisi, 6/4: 2182-2208.

ÖzYeTGiN, A. M. (2005), Orta Zaman Türk Dili ve Kültürü Üzerine İncelemeler, İstanbul: Ötüken Yayınları.

ÖzYetGin, A. M. (2006). “Tarihten Bugüne Türk Dili Alanı”, (Konferans Metni, Çin). 


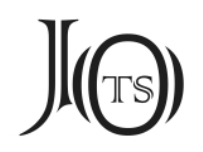

PEKACAR, Ç. \& F. M. UÇAR. (2011). "Nevşehir ve Diğer Anadolu Ağızlarında Fiillerin Teklik 3. Şahıs Çekimlerinde /n/ Sesi”, I. Uluslararası Nevşehir Tarih ve Kültür Sempozyumu Bildirileri, Nevşehir Üniversitesi Yayınları, Nevşehir: 225-236.

Poppe, N. (2008). “Altay Dillerinde Çokluk Ekleri”, Çev. C. KerimoĞLu, Dil Araştırmalar1 Dergisi, 2, 93-110.

Radloff, W. (2006). Sibirya'dan Seçmeler, Çev. A. Temir, İstanbul: Selenge Yayınlar1.

RAMSTEDT, G. J. (1957). Einführung in die altaische Sprachwissenschaft I: Lautlehre, Helsinki: Mémoires de la Société Finno-Ougrienne.

ReZAEi, M. (2017). “Avrasyatik Dil Teorisi Bağlamında Türkçe ve Farsça'nın Konumu”, Türkbilig, 25: 27-38.

ReZAei, M. (2018). “Ķa Zamiri Ve Onun Türevleri Hakkında Bazı Tespitler”, Söylem Filoloji Dergisi, 3/2: 272-283.

Róna-Tas, A. (2013). Türkolojiye Giriş, Çev. İ. SARI, Ankara: Nobel Akademik Yayıncllik.

SARI, İ. (2013). "Dil Etkileşimi Bağlamında Ses-Anlam Eşlemesi ve Türkçedeki Örnekleri”, Türk Kültürü, 1:1-27.

SCHARLipP, W. E. (2004). “The Decipherment of the Turkish Runic Inscriptions and its Effects on Turkology in East and West", Journal of Turkish Civilization Studies, 1: 303-318.

SERTKAYA, A. (2014). “Köl Tigin, Tunyukuk, Bilge Kağan, Ongi, Taryat, Şine Usu Gibi Göktürk Harfli Yazıtlarda 'Aykırı Genizleşme (Denazalizasyon)' Örnekleri”. Gazi Türkiyat, 1: 1-12.

SERTKAYA, O. S. (2011). “Kışkırtmak Kelimesinin Kökeni Üzerine”, Türk Dili, 717: 233-239.

SeVer, Z. (2019). "Semen Ulyanoviç Remezov'un Sibirya Atlası (Çertejnaya Kniga Sibiri)”, Genel Türk Tarihi Kaynakları Ordu Çalıştayı Bildirileri, Ed. M. AlPARGU et al. Ordu Büyük Şehir Belediyesi Kültür Yayınları, Ordu: 283-293.

SEvinçLi, V. \& S. ÇiçEK (2019). “Türkçede Ses Türemesi, Orhun Yazıtlarından Evliya Çelebi Seyahatnamesine Kadar”, Bingöl Üniversitesi Sosyal Bilimler Enstitüsü Dergisi, 9 18: 1233-1272. 


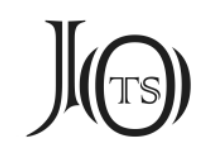

SoYdAN, S. (2017). “Orhon Kitâbelerinde Kök Halinde ve Türemiş Olan Bazı Kelimelerde Olumlu ve Olumsuz Anlam”, International Journal of Languages' Education and Teaching, 5/4: 869-885.

STACHowsKi, M. (2011). Etimoloji, Ankara: Türk Kültürünü Araştırma Enstitüsü Yayınları.

TAmir, F. (2003). “Türkiye Türkçesi Açısından Kazak Türkçesine Bir Bakış”, Selçuk Üniversitesi Türkiyat Araştırmaları, 13: 321-331.

TEKiN, Ş. (2001). İştikakçının Köşesi, İstanbul: Simurg Yayınları.

Tekin, T. \& M. Ölmez (2003). Türk Dilleri-Giriş, İstanbul: Yıldız Dil ve Edebiyat Yayınları.

TEKiN, T. (1968). A Grammar of Orkhon Turkic, Bloomington: Indiana University.

TeKin, T. (1975). Ana Türkçede Aslî Uzun Ünlüler, Ankara: Hacettepe Üniversitesi Yayınları.

Tekin, T. (1979). "Once More Zetacism and Sigmatism Main Pillars of the Altaic Theory “, Central Asiatic Journal, 30/1-2: 141-160.

TEKIN, T. (1987). Tuna Bulgarları ve Dilleri, Ankara: Türk Dil Kurumu Yayınları.

TEKin, T. (1993). Japonca ve Altay Dilleri, Ankara: Doruk Yayınları.

TEKin, T. (2000): Orhon Türkçesi Grameri, Ankara: Simurg.

Tekin, T. (2003). Orhon Türkçesi Grameri, İstanbul: Kitap Matbaası.

TEKin, T. (2004). Irk Bitig, Eski Uygurca Fal Kitabı, Ankara: Öncü Kitap.

Tekin, T. (2010). Orhon Yazıtları, Ankara: Türk Dil Kurumu Yayınları.

TOKER, M. (2013). "Köktürkçede Yön Bildiren Kelimeler ve Bunların Okunuşuna Farklı Bir Bakış”, Selçuk Üniversitesi Türkiyat Araştırmaları, 34: 1-10.

TunA, O. N. (1983). Altay Dilleri Teorisi, İstanbul: Türk Dünyası Araştırmaları Vakfı.

TunA, O. N. (1988). “Göktürk Yazılı Belgelerde ve Uygurcada Uzun Vokaller”, Türk Dili Araştırmaları Yıllı̆̆ı Belleten 1960: 213- 282.

TunA, O. N. (1990). Sümer ve Türk Dillerinin Tarihî İlgisi ile Türk Dilinin Taşı Meselesi, Ankara: Türk Dil Kurumu Yayınları.

TurAn, A. (1991). “Törelerimizde ‘Kalın’ (Başlık) Âdeti”, Millî Folklor, 12: 39-42. 


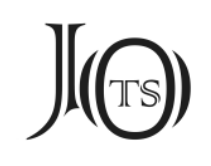

TuRAN, Z. (2012). "Eski Türkçe Döneminde Bir Morfofonetik Karşıtlık Sorunu", TEKE: Uluslararası Türkçe Edebiyat Kültür Eğitim Dergisi, 1/1: 69-80.

ÜNLÜ, S. (2013). Çağatay Türkçesi Sözlüğü, Konya: Eğitim Yayınevi.

ÜsTÜNER, A. (2015). Türkçenin Tarihî Gelişmesi, İstanbul: Bilge Kültür Sanat Yayınlar1.

Wallace, V. A. (2020). Sources of Mongolian Buddhism, London: Oxford Press.

YILMAZKAYA, E. (2017). “Eskicil/Eskicillik Kavramları ve Çuvaşça Üzerine”, The Journal of Academic Social Sience Studies, 55: 145-152.

ZENGin, A.\& Ü. Yaman (2018). “Eski Uygur Türkçesi Metinleri Üzerinden Budizm ve Maniheizm'in Savaşa Bakışı”, İstanbul Üniversitesi Türk Dili Ve Edebiyatı Dergisi, 58/1: 175-216. 